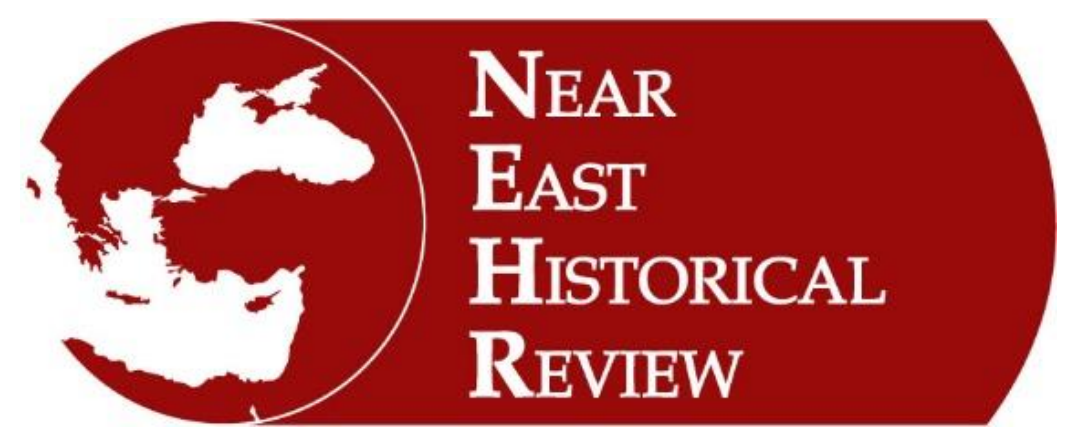

\title{
İZMİT KERESTE NAZIRI OSMAN EFENDİ: MEMURIYYTİ, VAKFI VE MUHALLEFÂTI
} Izmit Timber Custodian Osman Effendi: His Tenure, His Waqf and His
Mukhallafat

\author{
Meryem Kaçan Erdoğan \\ Prof. Dr., Eskişehir Osmangazi Üniversitesi, Türkiye \\ e-mail: meryem@ogu.edu.tr \\ ORCID ID: 0000-0002-8885-0936
}

Near East Historical Review

11/2, April / Nisan 2021

e-ISSN: 2717-6363 (Online)

www.nehrreview.com

\author{
Article Type - Makale Türü : Research Article / Araştırma Makalesi \\ Received Date-Geliş Tarihi : 11.03.2021 \\ Accepted Date - Kabul Tarihi : 07.04.2021 \\ Pages-Sayfa : $19-39$ \\ doi : http://dx.doi.org/10.29228/nehrreview. 50042
}

Citation-Attf : Meryem Kaçan Erdoğan, "İzmit Kereste Nazırı Osman Efendi: Memuriyeti, Vakfı Ve Muhallefâtı", Near East Historical Review, 11/2, April, 2021, pp. $19-39$ 



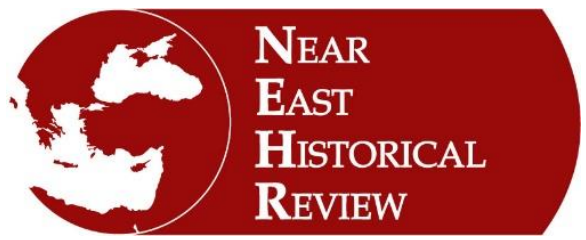

Near $\boldsymbol{E}$ ast Historical Review

11/2, April - Nisan 2021

19 - 39

Research Article - Araştırma Makalesi

\title{
IZMIT KERESTE NAZIRI OSMAN EFENDİ: MEMURIYYETİ, VAKFI VE MUHALLEFÂTI
}

\author{
Izmit Timber Custodian Osman Effendi: His Tenure, His Waqf and His Mukhallafat
}

\author{
Meryem Kaçan Erdoğan \\ Prof. Dr., Eskişehir Osmangazi Üniversitesi, Türkiye \\ e-mail: meryem@ogu.edu.tr \\ ORCID ID: 0000-0002-8885-0936
}

$\ddot{O} z$

Süleyman Penâh Efendi'nin oğlu olan Osman Efendi, aslen Moralı'dır. Maliyeden yetişerek çeşitli devlet görevlerinde bulunmuş, 1813-1818 yılları arasında İzmit kereste nazırı olarak görev yapmıştır. Memuriyeti süresince Tersâne-i Âmire'nin kereste ve kirpas ihtiyaçlarının temin edilmesinde ve İstanbul'a gönderilmesinde gayret göstermiş, İzmit Tersanesi'nin yeniden inşa edilmesine nezaret etmiştir. Ayrıca Sakarya Nehri'nin Sapanca Gölü ile ve bu gölün İzmit Körfezi'yle birleştirilmesi amaciyla hazırlanan projede görev almış, bölgenin keşfine memur edilen heyetle birlikte çalışmıştır. Bölgesindeki gelişmeleri yakından takip eden Osman Efendi, eşkıya ve eşkıyalık olayları hakkında merkezi bilgilendirmiş; yerel ayanların işledikleri suçların affedilmesi gibi bazı girişimlerde de bulunmuştur. Memuriyeti süresince İzmit'te ikamet eden Osman Efendi, hastalığı dolayısıyla zaman zaman İstanbul'a gidip gelmiştir. Son memuriyeti Saruhan nazırlığ Osman Efendi, aynı zamanda bir hayırsever olarak vakıf kurmuş, İzmit'teki Pertev Paşa Medresesi'ni bu vakıf aracılığıyla desteklemiştir.

Bu çalışmada çok yönlü bir kişiliğe sahip olan Moral Osman Efendi'nin kısa biyografisine işaret edilerek İzmit kereste nazırlığı dönemi, kurduğu vakfi ve memuriyetleri boyunca edindiği servetin bir yansımas olan muhallefâtı, arşiv belgeleri 1şı̆̆ında değerlendirilmiştir. Böylece Osman Efendi'nin şahsında, taşraya tayin edilen bir devlet görevlisinin yetkileri, şehre ve bölgeye katkıları, merkezle iletişimi ve yerel idarecilerle ilişkileri tespit edilmeye çalış1mıştır.

Anahtar Kelimeler: Moralı Osman Efendi, İzmit, Kereste Nazırı, Vakıf, Muhallefât.

\section{Abstract}

Osman Effendi, son of Suleiman Penâh Effendi, was originally from Morea. He was educated in finance and served in several government offices, including his service as a timber custodian in Izmit between 1813-1818. Osman Effendi tried hard to meet the Imperial Arsenal's (Tersânei Âmire) need for timber and linen cloth and to transfer them to Istanbul, and supervised the re-construction of the Izmit shipyard. He also took part in the project to connect the Sakarya river with the Sapanca lake, which was to be connected further to the Gulf of Izmit. Moreover, he worked with the delegation which had been assigned with the task of exploring this region. Osman Effendi informed the central administration about the events of banditry and even the bandits themselves as he closely followed the developments in his district. He also made certain initiatives such as pardoning the crimes of local notables. Osman Effendi resided in Izmit during his tenure and occasionally visited Istanbul due to his illness. His last office was in the Saruhan district. Being a philanthropist, he also established a religious foundation (waqf), which was intended to support the Pertev Pasha Madrasa in Izmit.

In this study, a brief biography of Moralı Osman Effendi as a versatile personality has been introduced and his custodianship of the timber in Izmit, the religious foundation he set up and the estate (mukhallafat) he left behind upon his death, which was a sign of the wealth he acquired during his services, have been analysed in the light of archival documents. Thus, the current research undertakes the task of illustrating the limits of the authorization of a government official in the countryside as represented by Osman Effendi as well as his contribution to the town and region he was assigned to, his communication with the central administration and his relations with local rulers.

Keywords: Moralı Osman Effendi, Izmit, Timber Custodian, Religious Foundation, Mukhallafat 


\section{Giriş}

Aslen Moralı olan Osman Efendi, Osmanlı Devleti'ne önemli hizmetlerde bulunmuş bir aileye mensuptur. Babas1 18.yüzyıl devlet adamı ve şairlerinden Süleyman Penâh Efendi, kardeşi ilk daimî Türk elçisi Yusuf Agâh Efendi'dir. Osman Efendi'nin oğlu Derviş Efendi de kendisi gibi hâcegân sınıfındandır. ${ }^{1}$

Maliyeden yetişerek başhalife, mektubî-i defterî, rikâb defterdarı, defterdar-1 ş1kk-1 evvel, tersane emini, nişanc1, çavuşbaşı, sadâret kethüdâsı, defter emini, Esma Sultan kethüdası, rikâb-1 hümâyûn kethüdası, kereste gümrüğü nazırı ve Saruhan nazırı olarak çok çeşitli görevlerde bulunmuştur. Çavuşbaşılık, sadâret kethüdâlığı, defterdarlık, nişancı, defter eminliği ve rikâb-1 hümâyûn kethüdalığı gibi görevlere birden fazla tayin edilmiştir. Saruhan nazırlığından sonra İstanbul'a gelen Osman Efendi burada vefat etmiştir. Mezarı Haydarpaşa'dadır. ${ }^{2}$ Yeni yazıya aktarılan Sicill-i Osmanî' de Osman Efendi'nin vefat tarihi 11 N 1232/25 Temmuz 1817 olarak

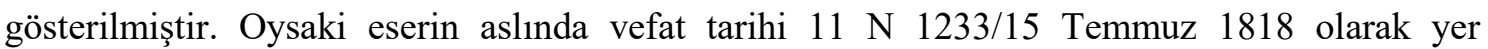
almaktadır. ${ }^{3}$ Bu tarih, Osman Efendi'nin muhallefât defterindeki kayıtlarla karşılaştırıldığında isabetli görünmektedir. Zira defterdeki ilk kayıtlar 18 Eylül 1818 tarihini taşımaktadır. Osman Efendi kaynaklarda vakur, dirayetli, zeki, hesap işlerini iyi bilen ${ }^{4}$, âlim ve fâzıl, nüfuzlu ve sağlam karakterli bir kişi olarak tarif edilmektedir. ${ }^{5}$

Hayatının büyük bir bölümünü devlet hizmetinde geçiren Osman Efendi, çeşitli görevler üstlenmiş, önemli hizmetlerde bulunmuştur. Mesela dağlı eşkıyasının iskânı, Fransızların Mısır'ı işgal etmesi karşısında, Devlet-i Aliyye'de bulunan Fransızların mal varlıklarının müsaderesi, işgalin sona ermesi üzerine Mısır'da düzenin yeniden kurulması gibi işlerde görev almıştır. Uzun memuriyet süresi, kurumların işleyen ve aksayan yönlerini tespit etmede kendisine önemli bir tecrübe kazandırmıştır. Düzenlenmesinde lüzum gördüğü meseleleri etraflıca tahkik etmiş ve meselenin çözümüyle ilgili görüşlerini takrirlerle ilgililere iletmiştir. Mali işlerde büyük başarılar kazanan Osman Efendi'nin ilk defterdarlık dönemine ait girişimleri, hazine için son derece faydalı olmuştur. Onun özellikle müsadere kurumunun sslahına dair hazırladığı takrir kayda değerdir. Osman Efendi, defterdar iken 1794 yılında III. Selim'e sunduğu bu takrirde gayrimeşru muhallefât zaptlarını, yetim malı-beytülmal ilişkisi açısından değerlendirmiş, devlet adamı, mültezim, esnaf ayırt edilmeksizin, biraz zengin olanların muhallefâtlarına el konulmasının ve muhallefât zaptlarında hukuki sınırın aşılmasının zararlı sonuçları üzerinde durmuştur. Müsadere kurumunun ıslahına dair yaptığı teklif, kurumun aslî yapı ve amacına geri döndürülmesi şeklinde olmuştur. $^{6}$

\footnotetext{
${ }^{1}$ Mahmud Esad Kalıpçı, "Müsadere Kurumunda Islaha Dair Bir Teklif: III. Selim Dönemine Ait Bir Vesika", https://dergipark.org.tr/tr/download/article-file/272849, s.259-260 (E.T.15.03.2020).

${ }^{2}$ Mehmed Süreyya, Sicill-i Osmanî, 4, Yayına Hazırlayan: Nuri Akbayar, Eski Yazıdan Aktaran: Seyit Ali Kahraman, İstanbul 1996, s.1291.

${ }^{3}$ Kalıpçı, "Müsadere Kurumunda Islaha Dair Bir Teklif”, s.261. Osman Efendi'nin vefat tarihi bazı yayınlarda 11 Ramazan 1231/5 Ağustos 1816 olarak gösterilmiştir [Fahri Ç. Derin, Yayla İmâmı Risâlesi, İstanbul Üniversitesi Edebiyat Fakültesi Tarih Enstitüsü Dergisi, Sayı 3, Ekim 1972, İstanbul 1973, s.220 (dipnot 17)].

${ }^{4}$ Mehmed Süreyya, Sicill-i Osmanî, 4, s.1291.

${ }^{5}$ Kalıpçı, "Müsadere Kurumunda Islaha Dair Bir Teklif”, s.261.

${ }^{6}$ Osman Efendi'nin kurumun ıslahına dair teklifi şu şekilde özetlenebilir: Gerek ricâlden ve gerekse diğer zenginlerden vefat edenlerin malvarlıkları, devlete borçları olmaması durumunda mirasçılarına teslim edilmeli, borcu olanların borçları resmî kayıtlardan yoklanarak tahsil edilmeli ve kalan meblağ mirasçılarına iade edilmelidir. Mirasçı bırakmadan ölenlerin muhallefâtlarının zabtı ise doğal bir uygulamadır. Ceza olarak malvarlıkları müsadere edilenlere yönelik uygulamaya ise devam edilmelidir. Ayrıca önerilen düzen büyük vezirlerin yetimleri hakkında da geçerli olmalıdır. Padişahın takrir hakkındaki kararı ise yetim malı ve miri ile bağlantısı olmayanların muhallefâtlarına dokunulmaması, devlet gelirlerinden servet edinen ricâl ve kibârın vefatları halinde mallarının beytülmale ait olduğu yönündedir. Osman Efendi’nin takriri hakkında ayrıntılı bilgi için bk. Kalıpçı, "Müsadere Kurumunda Islaha Dair Bir Teklif", s.253-284.
} 
Osman Efendi, aynı zamanda sosyal ve şer'i olaylara da büyük bir duyarlılık göstermiş ve bu duyarlılığı bir eserle de ortaya koymuştur. Veba hastalığı hakkında el-Mâûn fî-Meseleti't-Tâun adlı bir eser kaleme almıştır. Bunda babası Süleyman Penâh Efendi'yi vebadan kaybetmesinin de etkisi bulunmaktadır. ${ }^{7}$

Bu çalışmada Osman Efendi'nin İzmit kereste nazırı olarak bölgedeki faaliyetleri, kurduğu vakfi ve muhallefâtı incelenerek Osmanlı bürokrasisindeki etkinliği, diğer memurlarla oluşturduğu çalışma düzeni, aldığı sorumluluklar ve hizmetteki başarıları, topluma katkısı ve edindiği serveti değerlendirilmeye çalışlacaktır. Öncelikle İzmit kereste eminlerinin veya nazırlarının görev ve yetkileri üzerinde durmak gerekir.

\section{1. İzmit Kereste Eminleri veya Nazırları}

Kocaeli bölgesi, yüzy1llar boyunca gerek Tersâne-i Âmire'de gerekse diğer tersane ve işliklerde inşa edilen donanma gemilerine gereken keresteyi sağlamıştır. Bölgenin bir kereste nakliyat merkezi olması önemini bir kat daha artırmış ve bu amaçla İzmit'te bir Kereste Eminliği kurulmuştur. İzmit ve İstanbul tersanelerine kereste temin edilmesini düzenlemek üzere tayin edilen kereste eminlerine yardımcı olmak üzere kereste mübaşirleri görevlendirilmiștir. ${ }^{8}$ İzmit kereste eminleri veya nazırları, donanma inşası için gerekli olan keresteyi Tersâne-i Âmire'den gönderilen defterlere göre reayaya taksim etmiş ve en kısa zamanda teminine gayret göstermişlerdir. Kerestenin kestirilmesi, iskelelere nakli ve İstanbul'a gönderilmesi ile bedellerinin ödenmesi işinde çoğunlukla İzmit kereste emini görevlendirilmiş bazen de bu iş bıçkıcıbaşıya havale edilmiştir. Kereste eminlerinin tayinleri ve muhasebelerinin kontrolü, 1697 yılına kadar Tersâne-i Âmire Eminleri tarafindan yapılmış, bu göreve getirilen kişilerde işbilirlilik, doğruluk ve dindarlık gibi özellikler aranmıştır. Görev süresi 3 yıl olarak belirlenen kereste eminlerinden beklenen iş, Tersâne-i Âmire'de İzmit ocaklığı için ayrılan kereste mahzenine 21 kadırgalık kereste temin etmek ve bedellerini toplamaktan ibaretti. Kerestelerin reayadan temini ise ocaklık olanın avarız karşılığında, ocaklık fazlasının akçe karşılığında alınması şeklinde olmuştur. Kereste masraflarının ödenmesi, 1695 yılından itibaren Tersâne-i Âmire Emini yerine kereste eminleri tarafindan kereste için tahsis edilen bedellerden karşılanmıştır. Ocaklık haricinde alınan kerestelerin ücretleri ise miri akçeden kereste emini veya mübaşir vasıtasıyla reayaya dağıtılmıştır. Ocaklık tayin edilen bölgelerdeki ormanların korunması amacıyla görevlendirilen korucuların tayinleri de kereste eminlerinin arzı üzerine yapılmıştır. ${ }^{9}$ İzmit kereste eminleri, Tersâne-i Âmire'ye gönderilecek kerestenin zamanında kesimi ve nakli gibi görevlerin yanı sıra bölgenin ve yolların güvenliğinin sağlanması, eşkıyadan temizlenmesi, fakir ve zayıf halkın korunması ve sefer zamanında askerin zamanında çıkarılması gibi önemli görevler de üstlenmiştir. Bu yüzden İzmit kereste eminleri, seçkin görevliler olup aralarında Balabanzâde, Müderriszâde Mustafa ve Moralı Osman Efendi gibi tanınmış kereste eminleri bulunmaktayd $1 .{ }^{10}$

\footnotetext{
${ }^{7}$ Kalıpçı, “Müsadere Kurumunda Islaha Dair Bir Teklif”, s.262. Osman Efendi, eserinde Tanrı'nın insanlığın kaderini önceden belirlediği için alınan tedbirin kişinin Tanrı'ya olan güvenine ihanet edeceğini münakaşa etmiştir. O'nun için Müslümanın vereceği gerçek cevap kendini kadere teslim etmesi (tevekkül) ve Tanrı'nın vebaya yakalanan kişi ya da ailesine nimetini verdiği gerçeğidir. O, vebanın aslında kutsal savaşa eşit olduğunu farz etmektedir. Osman Efendi'nin veba hakkındaki görüşleri hakkında ayrıntılı bilgi için bk. Birsen Bulmuş, "Osmanlı İmparatorluğu'nda Veba Kavramları Üzerine: Mistisizimden Sosyal Reforma”, Motif Akademi Halkbilimi Dergisi, C.3, S.6, Y11 2010, s.45-51. ${ }^{8}$ Resül Narin, “Osmanlı'dan Cumhuriyet'e Ağaç Denizi Kocaeli”, Uluslararası Çoban Mustafa Paşa ve Kocaeli TarihiKültürü Sempozyumu-IV, Kocaeli 2017, s.974-975. Ayrıca bk. Resül Narin, "Osmanlı Devleti Zamanında Kocaeli Ormanları", Belleten, C.LXXV, Say1 274, Aralık 2011, s.771.

${ }^{9}$ İdris Bostan, Osmanlı Bahriye Teşkilâtı: XVII. Yüzyılda Tersâne-i Âmire, Ankara 1992, s.19, 104, 107-108, 110.

${ }^{10}$ Narin, "Osmanlı Devleti Zamanında Kocaeli Ormanları", s.771-772.
} 


\section{Osman Efendi’nin İzmit Kereste Nazırlığı Dönemi’ndeki Faaliyetleri}

İzmit kereste eminliğine "ashâb-1 nüfûzdan" bir kişinin tayin edilmesi gündeme geldiğinde, bu işe Limni adasında sürgünde olan ${ }^{11}$ ve orada cezasını çeken Osman Efendi düşünülmüş, kendisinin serbest bırakılarak kereste nezaretine tayin edilmesi kararlaştırılmıştır. Osman Efendi'nin tayin gerekçesinde "bu husûs kendüyü tahkîr olmayıp mücerred şu kereste maddesi dolaşı̆̆ı çözülsün içindir” ifadesi önemlidir. Merkez, Osman Efendi’ye güvenmekte ve onu işin üstesinden gelebilecek bir kişi olarak görmektedir. Defterdara gönderilen yazıdan anlaşıldığına göre Limni'de sürgünde olan Osman Efendi'nin serbest bırakılarak İzmit kereste nezaretine memur edilmesi emredilmektedir. Yazının tarihi 29 M 1228/1 Şubat 1813 olduğuna göre Osman Efendi, kısa süre sonra İzmit kereste nazırlığı görevine getirilmiş olmalıdır. ${ }^{12}$ Osman Efendi N 1231/Temmuz-Ağustos 1816 tarihinde Saruhan nazırlı̆̆ına atanıncaya kadar bu görevi bilfiil sürdürmüştür. Osman Efendi'nin görevde olduğu süre boyunca İzmit'te önemli gelişmeler olmuş, O doğrudan ya da dolaylı olarak bu gelişmelerin içerisinde yer almıştır.

\subsection{Tersâne-i Âmire'nin Kereste ve Diğer İhtiyaçlarının Karşılanması}

Kocaeli Sancağı'nda bulunan ormanlar, Osmanlı donanmasının ve Tersâne-i Âmire'nin ihtiyac1 olan kerestelerin büyük bir bölümünü karşıllyordu. ${ }^{13}$ Tersâneye gönderilen kereste ve gemi levazımı ambarlarda muhafaza edilmiş, bu ambarlar "mahzen-i sürb" ve "anbar-1 çûb" olarak tasnif edilmiştir. Kereste anbar-1 çûbda; gemi ve tersâne levazımı ise mahzen-i sürbde depolanmıştır. ${ }^{14}$ İzmit Kereste Nazırı Osman Efendi, memuriyeti boyunca talep edilen cins ve ebattaki malzemeleri her iki mahzene de göndermiştir. Tersâne-i Âmire'den gönderilen bir defter kapsamında ihtiyaç duyulan keresteler "kerestekeş" kazalar halkı tarafindan kesilmiş ve nakledilerek teslim edilmiştir. Kazaların taahhüt ettikleri kereste miktarı 7.500 kıta ağaçtan oluşmaktadır. Kazalar halkının hisselerine düşen miktarı azaltmak adına zaman zaman muaf reaya üzerine tevziatta bulundukları anlaşılmaktadır. Muaf reaya ise çeşitli muafiyet iddialarıyla bu yükümlülüğ̈̈n altına girmeyerek hisselerine düşen keresteyi vermemişlerdir. Dolayısıyla muaf reayanın üzerinde kereste bakaya olarak kaldığı gibi talep edilen miktarın da temin edilmesi mümkün olmamıştır. Osman Efendi'nin kereste maddesi gibi sorunlu bir alanın çözümünde bölgedeki kazaların muhtarlarıyla 1813 yılının Nisan ayında müzakereler yaptığı ve yeni tertipte hazırladığ defterleri yetkililere sunduğu tespit edilmiştir. Bu durumda, muaf reaya hariç tutularak 7.509 kıta kerestenin "kerestekeş" reayadan temin edilmesi kararlaştırılmıştır. ${ }^{15}$

Bölgenin ocaklık kerestesi, mahzenlere teslim edildikçe ödemeler de Tersâne hazinesinden yapılmıştır. 1815 yılında Osman Efendi İzmit’ten kesilen 4.329 adet birik ve şalope kerestesini mahzen-i çûba teslim etmiştir. Teslim edilen kerestenin 3.359 adedinin bedeli ödenmiş, 970 adet kerestenin 3.264 akçe tutan bedeli ise henüz ödenmemiştir. Bedelin tersane hazinesinden ödenmesi talimatı verilmiştir. ${ }^{16}$

33 zirân ${ }^{17}$ kordon kerestesi olarak istenen ağaçlar ise daha önce İzmit Kereste Nazırı Osman Efendi tarafından kestirilerek Tersâne-i Âmire'ye gönderilmişti. Kerestelerin bedeli 5.483 kuruş ve 654 adet ağaç olarak hesaplanmıştır. Bu teslimat dışında Tersâne-i Âmire'de inşa ettirilerek

\footnotetext{
${ }^{11}$ Osman Efendi'nin Limni’ye sürgün edilme sebebi bilinmemektedir. Sürgün fermanı çıktığında bir çavuş nezaretinde hanesine getirilmiş ve oradan alınarak sürgün yerine gönderilmiştir [BOA, Topkapı Sarayı Müzesi Arşivi Evrak (TSMA.E.), 710/39 (Tarihsiz)].

12 BOA, Hatt-ı Hümâyûn (HAT), 1262/48869-B, 1313/51185 (Tarihsiz).

${ }^{13}$ Narin, "Osmanlı Devleti Zamanında Kocaeli Ormanları", s.771.

${ }^{14}$ Bostan, Osmanlı Bahriye Teşkilâtı, s.9.

${ }^{15}$ BOA, Cevdet Bahriye (C.BH), 101/4895.

${ }^{16}$ BOA, C.BH, 137/6623 (16 Za 1230/20 Ekim 1815).

${ }^{17}$ Dirsekle orta parmak ucu arasındaki kısmı ifade eden kelimenin Arapçası zirâ, Türkçesi arşındır. Osmanlılarda kullanılan bir mimar arşınının değeri 1841 yılında 75,77 cm idi (Mehmet Erkal, “Arşın”, Türkiye Diyanet Vakfi İslam Ansiklopedisi, C.3, İstanbul 1991, s.411-412).
}

Near East Historical Review www.nehrreview.com 
denize indirilen 37 zirâ kordon gemileri için daha sonra bölgeden tekrar ağaç talep edilmiş, kestirilen 145 adet çeşitli cinsteki kereste mahzen-i sürbe teslim edilmiştir. Osman Efendi, tersaneye teslim edilen kerestelerin bedellerini talep etmiş ve bedeli olan 1.835 kuruşun $23 \mathrm{~L}$ 1231/16 Eylül 1816 tarihinde tersane hazinesinden ödenmesine karar verilmiştir. ${ }^{18}$ Yine aynı yılda padişahlar için sandal yapımında kullanılmak üzere ihtiyaç duyulan ağaçlar da İzmit'ten temin edilmiştir. Kereste Nazırı Osman Efendi, talep edilen 28 adet sandal ağacını Tersâne-i Âmire'ye göndermiş ve mahzen-i çûba teslim ettirmiştir. ${ }^{19}$

Tersâne-i Âmire'nin ihtiyaç duyduğu malzemelerden birisi de kirpastır. Mahzen-i sürbde depolanan kirpasın bir kısmı Geyve kazasından temin edilmiştir. Osman Efendi'nin nazırlığı döneminde 1081 top kirpas, kazada dokunarak satın alınmış ve tersaneye gönderilmiştir. ${ }^{20}$

\subsection{Palangaların Kereste İhtiyaçlarının Karşılanması}

İzmit Kereste Nazırı Osman Efendi'ye havale edilen işlerden birisi de palangalar için lüzumlu kerestenin temini meselesidir. Akdeniz boğazında bulunan Kilidülbahr ve Sultaniye kalelerinin dört bir tarafına inşa edilmesi kararlaştırılan 7 adet palanganın yerleri keşfedilerek planları yapılmıştır. Bu konuda Mimar Ağa'nın yanı sıra bölgeye gönderilen mühendis halifesinin görüşleri alınmış, keşif defterleri incelenmiş ve tahmini maliyet hesaplanmıştır. Buna göre 176 adet top ile 6 adet havanın konulması için inşa edilecek 7 adet kargir palanganın maliyeti, 1.533 kese akçe (küsur 156,5 kuruş) olarak hesaplanmıştır. Topların konulacağı tabyalar birbirine birer saat mesafe uzaklığında dördü Anadolu sahilinde, üçü Rumeli tarafında olacak şekilde planlanmış ve işi kolaylaştırmak amacıyla Anadolu ve Rumeli tarafı için ayrı bina eminleri ve maiyetlerine mühendis tayin edilmesi kararlaştırılmıştır. Ayrıca Kilidülbahr, Sultaniye, Seddülbahr ve Kumkale ile etrafında olan çit tabyalarda bulunan eskimiş top kundaklarının yenilenmesi için harekete geçilmiştir. Kundakların tamiri için çok sayıda keresteye özellikle karaağaç ve meşeye ihtiyaç olup bunların İzmit ve Gemlik tarafından kesilerek ilkbaharda gemilere yüklenmesi ve kalelere gönderilmesi gerekmektedir. Tabyaların inşası ile top kundaklarının tanzimi meselesi için görevliler tayin edilmiş, kundaklar için gerekli kerestenin temin edilme durumu da İzmit Kereste Nazırı Osman Efendi'ye sorulmuştur. Özellikle boğaza yakın yerlerde kereste tedarik edilecek başka yerlerin olup olmadığının araştırılması ve buna göre hareket edilmesi üzerinde durulmuştur. Sonuç olarak tabyalar ve kundakların tamir ve inşası amacıyla Feyzi Bey ve İbrahim Şeref Efendi tayin edilerek maiyetlerine mühendis, marangoz ve demirciler verilmesine; kerestenin temini konusunun Osman Efendi'den sorularak hazırlıklara başlanmasına ve masrafların kaleler tertibatından karşılanmasına karar verilmiştir. ${ }^{21}$

\section{3. İzmit Tersanesi'nin Yeniden İnşa Edilmesi ve Genişletilmesi}

XIX. yüzyılın başlarında İzmit Tersanesi harap bir görüntü çizmektedir. Evail-i Ş 1229/1928 Temmuz 1814 tarihli ferman, tersanenin durumunu gözler önüne sermektedir. İzmit Kereste Nazırı Osman Efendi başta olmak üzere Kocaeli Sancağı'ndaki görevlilere gönderilen fermanda, tersanenin yeniden inşa edilmesiyle ilgili önemli açıklamalar yer almaktadır. Fermanın gönderildiği sıralarda tersane ve tersanede bulunan odalar son derece harap durumdadır. Halbuki başlangıçta tersane, harem ve selamlıklı bir daire olarak gayet muntazam şekilde inşa edilmişken daha sonra çıkan yangın bütün bu bölümlerin yanmasına ve harap olmasına sebep olmuştur. Tersane mevcut durumda harap iki odadan oluşmaktadır. Ayrıca tersaneyi çevreleyen duvarlar yeterince yüksek olmadığından geceleri içerisine bazı kişiler ve hayvanlar girmektedir. Bundan da önemlisi tersane her gün kereste eminlerinin, kâtiplerin, kolcuların ve kereste getiren

\footnotetext{
${ }^{18}$ BOA, C.BH, $113 / 5469$.

${ }^{19}$ BOA, C.BH, 68/3210.

${ }^{20}$ Kirpasın İstanbul'da fiyatı yüksek olduğundan Geyve'den temin edilmiştir. Bedeli olan 3.243 kuruşun Tersâne-i Âmire hazinesinden verilmesi hakkında bk. BOA, C.BH, 81/3891 (17 M 1232/7 Aralık 1816).

${ }^{21}$ BOA, HAT, 1591/18 (Tarihsiz).
} 
arabacıların toplandığı, bütün kereste işlerinin görüldüğü ve idare edildiği bir yerdir. Tersanenin yenilenmesiyle ilgili gelen ferman, burada iki oda, sofa ve kahve ocağından oluşan bir selamlığın yapılmasından, tersanenin etrafını çevreleyen duvarlardan gerekli kısımlarının yükseltilmesinden bahsetmektedir. Tersanenin yeniden inşası için bir maliyet hesaplaması da yapılmış ve masrafın 15.000 kuruş tutarında olacağı tahmin edilmiştir. Bu paranın Kocaeli Sancağı'ndaki reayaya adaletli bir şekilde tevzi edilerek tahsil edilmesi kararlaştırılmıştır. Tersanenin inşasıyla ilgili işler, Hassa silahşorlardan İzmit Ayanı sabık Mir Ali'ye havale edilmiş, inşa işine nezaret etme görevi de İzmit Kereste Nazırı Osman Efendi’ye verilmiştir. Osman Efendi, tamir ve inşa edilecek yerlerin tamamlanması, harcamaların usulüne uygun olarak yapılması ve masrafların keşif defterine kaydedilerek İstanbul'a gönderilmesinden sorumlu tutulmuştur. Merkez, keşif defterindeki harcama kayıtlarının esas alınmasını, reayadan fazla para talep edilmemesini istemiş, bölgedeki görevlilerin talimatlara uygun şekilde hareket etmelerinin önemini vurgulamıştır. ${ }^{22}$

\section{Girișimleri}

\subsection{Sakarya Nehri-Sapanca Gölü-İzmit Körfezi’nin Kanalla Birleştirilmesi}

Sakarya Nehri'nin Sapanca Gölü'ne ve Sapanca Gölü'nün İzmit Körfezi'ne akıtılması girişimleri ilk defa Kanuni döneminde gündeme gelmiş, bölgede birtakım çalışmalar başlatılmış ancak savaşlar nedeniyle bir sonuç alınamamıştır. Proje, III. Murad döneminde tekrar ele alınmış, ihtiyaç duyulan gemi kerestesinin nehir yoluyla ve hızlı bir şekilde denize indirilmesi öncelikli amaçlar arasında yer almış, sonraki girişimlerde buna ekonomik sebepler de eklenmiştir. Ölçümlerin yapılması için bölgeye mimar ve mühendislerden oluşan bir heyet gönderilmiş, kanalda çalışacak amele ve ırgatların temini için de hazırlıklar başlatılmıştır. Ancak kanal açılmasına karşı olanların girişimiyle bu işe son verilmiştir. 1654 yılında kanal projesi tekrar gündeme gelmiş, bölgede keşif yaptırılarak raporlar hazırlanmıştır. Raporlarda arazinin kazılmasının zorluğu ve çevrenin büyük zararlar göreceği dile getirildiğinden kanaldan üçüncü defa olarak vazgeçilmiştir. I. Mahmud döneminde İstanbul'un ekonomik darlığı göz önüne alınarak sadece Sapanca Gölü ile İzmit Körfezi'nin birleştirilmesi düşünülmüş, keşif yapılmasına rağmen bu girişimden de sonuç alınamamıştır. 1759 yılında bu işe tekrar teşebbüs edilmiş, Sapanca Gölü-İzmit Körfezi, Sakarya Nehri-Sapanca Gölü’nün birleştirilmesi gibi iki seçenek üzerinde durulmuştur. Bölgede hafriyata başlanmış ancak suyun çıkması, kışın gelmesi ve çeşitli engeller yüzünden çalışmaya ara verilmiş sonra da vazgeçilmiştir. ${ }^{23}$

1813 yılında ise kanalın açılmasıyla ilgili teşebbüs, Kocaeli ve Hüdavendigar sancaklarında mutasarrıf olan Vezir Hacı Ahmed Aziz Paşa tarafından yapılmış, kanalın ekonomik önemine dikkat çekerek bölgenin tetkiki, ölçüm ve resimlerinin yapılması için heyet gönderilmesini talep etmiştir. Merkez, kısa sürede bu işe sabık Çavuşbaşı Abdullah İffet Bey'i memur ederek maiyetine iki mühendis ile bir mimar tayin etmiştir. Evail-i N 1228/28 Ağustos-6 Eylül 1813 tarihli ferman ile işe memur edilenler hakkında Aziz Paşa'ya bilgi verilmiştir. Heyetin önce Aziz Paşa ile durumu müzakere etmesi ve kararın verilmesinden sonra bölgede ölçüm, plan ve teknik hesapları yapması, maliyeti çıkarması ve amele sayısını belirlemesi gerekiyordu. Ayrıca görevliler, bölgedeki incelemelerini ayrıntılı bir rapor halinde merkeze sunacaklardı. İlk heyetin gitmesinden kısa bir süre sonra, işin öneminden dolayı bölgeye 7 kişilik bir fen heyeti daha gönderilmiştir. Keşif heyeti gerekli tetkikleri yapmış, heyetten iki kişi (Mühendis Ahmed ve Mehmed Efendiler) Aziz Paşa tarafindan Sakarya Nehri’nin kaynağından Sapanca Gölü’ne kadar olan sahada araştırma yapmaya memur edilmiştir. Mühendislerin ayrıntılı raporlarını merkeze sunmaları üzerine kanal işi, Aziz Paşa'ya havale edilmiştir. Raporda, kanalın geçeceği

\footnotetext{
${ }^{22}$ Meral Akşener, İzmit Şer'iyye Sicili (4 Muharrem 1220-25 Şevval 1230) (4 Nisan 1805-30 Kasım 1814), Marmara Üniversitesi Türkiyat Araştırmaları Enstitüsü, Yayımlanmamış Doktora Tezi, İstanbul 1992, s.147-148.

${ }^{23}$ Kanal girişimleriyle ilgili ayrıntılı bilgi için bk. İsmail Hakkı Uzunçarşılı, "Sakarya Nehrinin İzmit Körfezine Akıtılmasiyle Marmara ve Karadenizin Birleştirilmesi Hakkında”, Belleten, C.IV, Sayı 14-15, Nisan-Temmuz 1940, Ankara 1994, s. 149-174.
} 
güzergâhtan mal, hayvan, zahire ve kerestenin sallar ile İzmit'e rahatça gönderileceğine ve daha birçok faydasının olacağına işaret edilmiştir. Merkez, Evâsıt-1 Z 1228/5-14 Aralık 1813 tarihli fermanla Aziz Paşa'dan hazırlıklarını yapmasını ve uygun gördüğü bir zamanda işe başlamasını istemiştir. ${ }^{24}$ Fermanda geçmemesine rağmen kanal işine memur edilenler arasında İzmit Kereste Nazırı Osman Efendi de bulunmaktadır. Şânîzâde Tarihi'nde "Keşf-i Nehr-i Sakarya” başlığı altında Osman Efendi'nin Aziz Paşa, Çavuşbaşı Abdullah İffet Bey ve maiyetlerinde bulunan mühendislerle birlikte Eylül 1813 tarihinde keşfe memur edildiğinden bahsedilmektedir. Kayda göre keşif heyeti, nehir havalisini dolaşarak gerekli yerlerin uzunluk ve derinliğinin ölçülmesi, nehir içindeki kayalar, doğal setler ve sığ yerlerin yerinde görüp incelenmesi, Sapanca Gölü’nden körfeze kadar olan sahanın teknik aletler, reis ve işçilerin yardımıyla ölçümlerinin yapılması gibi işleri gerçekleştirmiştir. Ancak hazırlıkların yapılma emrini içeren fermandan 20 gün sonra, Aziz Paşa vefat etmiş, onun vefatıyla kanalın açılma girişimi bir kez daha sonuçsuz kalmıştır. ${ }^{25}$

\subsection{Eşkıyanın Yakalanması ve Cezalandırılması}

Bölgedeki eşkıyalık olaylarına karşı, İzmit Kereste Nazırı Osman Efendi’nin eşkıyanın takip edilmesi ve yakalanması konusunda yerel görevlilerle birlikte hareket ettiği ve gelişmeleri Kocaeli mutasarrıflarına bildirdiği görülmektedir. Nitekim 29 M 1230/11 Ocak 1815 tarihinde Osman Efendi'nin İzmit Mütesellimi Ali Ağa ile birlikte Kocaeli Mutasarrıfı Mustafa Paşa'ya gönderdikleri müşterek mühürlü bir şukkadan eşkıyanın kimliği ve himaye edenlerin isimlerine ulaşılmaktadır. Sakarya, Adapazarı civarında faaliyet gösteren Kapusuz Mustafa, son olarak Genceli kazasını basarak halktan para toplamak istemiş, epey süren mücadeleden sonra ayanını katletmiş ve Kartal Ayanı Ömer Ağa'nın yanına sığınmıştır. Eşkıyanın burada olduğu bilgisi Genceli'deki muhtar vekili Tarakçığlu Ahmed Ağa tarafindan tespit edilmiş ve gizli olarak kendilerine bildirilmiştir. Osman Ağa ile Ali Ağa kendilerine ulaşan bilgiyi Kocaeli mutasarrıfına iletmişler ve durumdan haberdar olmasını sağlamışlardır. ${ }^{26}$

Bölgedeki bir başka ciddi tehdit de Adapazarı Ayanı Kara Osman Ağa idi. Kocaeli ve Sakarya bölgesinin en namlı ve kudretli ayanlarından biri olarak 1800'lü yılların başından 1816 yılına kadar bölgede varlığını hissettirmiş ve merkezi idareyi uzunca bir süre meşgul etmiştir. Merkez açısından Kara Osman, emirleri dinlemeyen, halka zulmedip baskıda bulunan, fesat çıkaran bir kişiydi. 1803 yılından itibaren Kara Osman Ağa'nın reaya üzerindeki baskısı nedeniyle harekete geçen merkez, onu birçok kez affetmesine rağmen 1816 y1lına gelindiğinde kanun dışı hareketlerinin devam etmesi üzerine yakalanmasını ve cezalandırılmasını emretmiştir. ${ }^{27}$ Nurullah Paşa bizzat harekete geçmiş, durumdan civar kazalar halkı da haberdar edilmiştir. Ancak paşanın hareketinden önce Kara Osman 25 Ca 1231/23 Nisan 1816 tarihinde Salı gecesi kardeşlerini ve kendisine tabi olan bir grubu yanına alarak dağa firar etmiştir. İzmit Kereste Nazırı Osman Efendi, 26 Ca 1231/24 Nisan 1816 tarihli şukkasıyla gelişmeleri an be an ayrıntılı bir şekilde merkeze bildirmiştir. Buna göre Osman Efendi, Adapazarı Naibi Feyzullah Efendi'den kendisine bir ilam geldiğini, ilamda olaydan ahalinin hiçbir şekilde zarar görmediği ve mütesellim ile paşanın gelişmeler hakkında bilgilendirildiği haberini aldığını ifade etmiştir. Ayrıca Osman Efendi, Kara Osman'ın firar ettiği dağı bilirkişilerden soruşturmuş ve Adapazarı civarında Sinanlıŏ̆lu Dağı adıyla uçsuz bucaksız ve meşhur bir dağ olduğunu, daha önce de Kara

\footnotetext{
${ }^{24}$ Uzunçarş111, "Sakarya Nehrinin İzmit Körfezine...”, s.161-166.

${ }^{25}$ Şânî-zâde Târîhi, C.2, Dersaadet 1290, s.202-203; Uzunçarşıl1, keşfe ait bir resmin mevcut olduğunu ancak elde edilemediğini ifade etmiştir (“Sakarya Nehrinin İzmit Körfezine...”, s.166-167, 174).

${ }^{26}$ BOA, HAT, 286/17170. Devlete son derece itaatkâr görünüp İstanbul'un yanı başında eşkıyaya yataklık eden Kartal Ayanı Ömer Ağa, mutasarrıfa gönderdiği yazıda, şakinin kazası dâhilinde olmadığını, gelirse yakalanacağını ifade etmekle birlikte merkezi idarenin kendisine güvenmediği ve gizlice durumunun takip edilmesi emrini verdiği anlaşılmaktadır [Atilla Çetin, "Kocaeli ve Hüdavendigar Sancaklarında Eşkiyalık Olayları (18. ve 19. Yüzyıllar)", Osmanlı'dan Günümüze Eşkıyalık ve Terör, Ed. Osman Köse, Samsun 2017, s.143-144].

${ }^{27}$ Ayrıntılı bilgi için bkz. Atilla Çetin, “Adapazarı Âyanı Kara Osman Ağa Vakfı ve Vakfiyesi”, Vakıflar Dergisi, S.30, Ankara 2007, s. 155-166.
} 
Osman'ın zor durumda kaldıkça buraya sığındığını öğrenmiştir. Bu şekilde Osman Efendi merkezi çok hızlı bir şekilde bilgilendirmiş ve tedbir alma sürecini hızlandırmıştır. Merkez, Kara Osman'ın Bolu veya İzmit'e gitme ihtimaline karşı ölü veya diri olarak yakalanması için daha önce Bolu Sancağı mutasarrıfi ile Osman Efendi'yi haberdar etmiştir. Son durumda Adapazarı civarındaki dağa firar ettiği bilinen ayanın İstanbul'a veya başka yerlere gitme ihtimali de olduğundan takip edilmesi ve yakalanması üzerinde durulmuştur. Padişah, Adapazarı'nda yeni bir ayan seçilmesini, Kara Osman'ın kazaya sokulmamasını, eşkıyanın yakalanıp idam edilmesi için gereken tedbirlerin alınmasını ve İstanbul güzergâhına dikkat edilmesini emretmiştir. ${ }^{28}$ Nitekim, Kara Osman Ağa sıkı bir takip sonucunda 1816 yılının Mayıs ayı sonunda yakalanarak idam edilmiştir. ${ }^{29}$

\subsection{Ayanların Soruşturulması ve Affı Konusu}

Osman Efendi, sadece kerestenin temininden sorumlu olmamış aynı zamanda bölgedeki gelişmeleri takip etmiş, haksızlık ve yolsuzların araştırılması için merkeze mektuplar göndermiştir. Merkezin emriyle zaman zaman bir müfettiş ve soruşturmacı olarak da görev yapmıştır. Özellikle kaza ayanlarının reaya üzerindeki baskısı, kanun dışı vergi talepleri ve salma iddialarının etraflıca araştırılması ve soruşturulması işi Osman Efendi'ye havale edilmiştir. Nitekim Geyve reayası, birçok kez merkeze gönderdiği arzuhaller ile ayanları Bekir Ağa ile kardeşi İsmail Ağa ve kethüdası Hacı Mehmed'den şikâyetçi olmuşlardır. Söz konusu kişiler, kaza reayasının ödemekle yükümlü olduğu masraf ve vergilerin birkaç katını tahsil etmişler, ancak tahsilâtı kazanın sicil defterlerine kaydetmemişlerdir. Ayrıca, vefat edenlerin terekelerinden alınan resm-i kısmeti kendileri alıp aylıklı naip tayin etmişler, dolayısıyla reayanın hukukunu çiğnemişlerdir. Bunların dışında Geyve reayası, kereste bedeli ile menzil masraflarını ödemesine rağmen menzil ve vilayet masrafi, odun mübayaası, kalyon kerestesi bedeliyesi, menzil imdadiyesi gibi çeşitli salmalarla muhatap olmuşlardır. Reayanın arzuhalleri üzerine olayın soruşturulması için harekete geçilmiş ve bu işe İzmit Kereste Nazırı Osman Efendi memur edilmiştir. Osman Efendi, soruşturma sırasında sancak valisi Hacı Mustafa Paşa'nın Geyve kazasına uğradığında kendisine sunulan bir yıllık sâlyâne defterini onayladığını ancak kayıtların titiz bir şekilde kontrol edilmediğini, alınan masrafların başka bir defter ile tevzi ve tahsil edildiğini ortaya çıkarmıştır. Osman Efendi, kazadan 1229/1813-1814 senesine mahsuben kereste tertibi akçesi olarak 15.520 kuruş aldığını, ancak ayanın bu miktarı 17.641.5 kuruş olarak reayaya tevzi ve taksim ettiğini, kazada aylıklı olarak görevlendirilen naip için de 2.500 kuruş aldığını tespit etmiştir. Araştırmalarını derinleştiren Osman Efendi, kazanın bir yıllık kalyoncu bedeliyesi ve odun masrafi olarak kaza ve köylerinden 11.000 kuruş tahsil edilmesi gerekirken 20.085 kuruş tahsil edildiğini, bu miktarın içerisinde valinin hazariyye taksiti, mübaşiriyye hizmeti ile memleket sermayesi adıyla çeşitli masrafların da olduğunu görmüştür. Osman Efendi, reayadan fazladan tahsil edilen 7.700 kuruştan fazla meblağın ayanın elinde ziyan olacağı endişesini dile getirmiştir. Menzil imdadiyesi hakkındaki araştırmaları ise Bekir Ağa'nın bu konuda herhangi bir yolsuzluğunun olmadığı şeklinde sonuçlanmıştır. Osman Efendi, araştırma sonuçlarını ayrıntılı ve titiz bir şekilde 3 B 1230/11 Haziran 1815 tarihli bir yazıyla merkeze bildirmiştir. Merkez, ayanın suçu sabit olmasına rağmen üç ayların hürmetine idam etme yoluna gitmemiş sadece görevden azlederek sürgün kararı vermiş, ayanın Magosa'ya, kardeşinin diğer adalara sürülmesini, reayadan fazla tahsil edilen paranın da malından tahsil edilmesini emretmiştir. ${ }^{30}$

Osman Efendi, ayanın sürgün edilmesinin üzerinden bir yıl geçtikten sonra bu kez arabulucu olarak giriş̧imde bulunmuştur. Padişahın hattıyla "katle bedel Magosa"ya sürülen eski ayan Bekir Ağa, affı için Kereste Emini Osman Efendi'den arabulucu olmasını istemiş, sürgünün

\footnotetext{
${ }^{28}$ BOA, HAT, 631/31171.

${ }^{29}$ Çetin, “Adapazarı Âyanı Kara Osman Ağa Vakfi ve Vakfiyesi”, s. 166. Ayrıca bk. Çetin, "Kocaeli ve Hüdavendigar Sancaklarında Eşkiyalık Olayları", s.144-145.

${ }^{30}$ BOA, HAT, 506/24903.
} 
üzerinden yaklaşık bir y1l geçtiğini, "1slah-1 nefs" ettiğini ve Geyve’ye gitmeyip başka bir yerde ikamet etmek şartıyla affedilip serbest bırakılma isteğini dile getirmiştir. İstanbul'da bulunduğu zamanlarda durumu sadarete arz eden Osman Efendi'ye gerek ayanın gerekse kardeşi İsmail'in serbest bırakılacağına dair vaatte bulunulmuştur. Ayanın ailesi de affedilmesi ve serbest bırakılması için merkeze arzlar göndermiș, hatta ayanın oğlu ricada bulunmak üzere İstanbul'a hareket etmiştir. Sadaret, Osman Efendi'nin 15 Ca 1231/13 Nisan 1816 tarihli şukkası üzerine Bekir Ağa'nın Geyve ve civar kazalara ayak basmamak, İstanbul veya başka bir yerde ikamet etmek şartıyla serbest bırakılmasını padişahın iradesine bırakmıştır. Padişahın kararı "Geyve ve civarında olan kazalara ayak basmayup Bursa veyahut Asitane'de ikamet eylemek şartıyla iyâl ve evlâdına merhameten afv ve itlak oluna" şeklinde olmuştur. Dolayisıyla Osman Efendi'nin girişimleri başarılı olmuş ve eski ayan serbest bırakılmıştır. ${ }^{31}$

\subsection{Osman Efendi’nin Saruhan Sancağı Muhassıllığı'na Gönderilmesi}

Batı Anadolu'da söz sahibi önemli ailelerden biri olan Karaosmanzâdeler ailesinden Hüseyin Ağa, 1816 yılının Mart ayında vefat etmiştir. Saruhan Sancağı'nın mukataalarını ve pek çok timar ve zeameti kendisinde toplayan Hüseyin Ağa'nın ölümüyle beraber merkezi idare muhallefâtın zaptı ve kardeşlerinin başka yerlere iskânı amacıyla bölgeye devlet ileri gelenlerinden Abdi Ağa'yı göndermiştir. Bunun yanı sıra, bölgeyi mütegallibeden kurtarmak ve doğrudan doğruya merkezden yönetmek üzere devlet ileri gelenlerinden Moralı Osman Efendi'yi Saruhan Sancağ 1 nazırı olarak tayin etmiştir. ${ }^{32}$ Osman Efendi'nin tayin tarihi Evâhir-i Za 1231/Kasım 1816 olarak gösterilmektedir. ${ }^{33}$ Oysaki Ekim 1816 tarihinde Osman Efendi, Saruhan Sancağı muhassılı olarak merkeze bir yazı göndermiştir. İzmit kereste nazırlığı görevinde iken Saruhan Sancağı muhassıllığına getirilen Osman Efendi, İzmit'teki kereste işlerini idare ve takip etmek üzere kethüdası Eyüp Ağa'yı vekil olarak bırakmıştır. Görev yerine gitmeden önce, Eyüp Ağa'ya gerekli tenbih ve ikazlarda bulunan Osman Efendi'nin Saruhan Sancağı muhassillık görevinin son derece önemli olduğu ve merkezin beklentilerine cevap vermek üzere bu sorumluluğu üstlendiği görülmektedir. Osman Efendi'nin muhassıllık görevinde iki husus dikkati çekmektedir. Bunlardan biri, sancağa vardığında merkezin talimatları doğrultusunda hareket ederek yapacağı tahkikatları merkeze bildirmesi, diğeri de sancak dâhilinde olan iltizam ve mukataaların miriye ait gelirlerini geçmiş yılları da hesaba katarak tahsil etmesidir. Osman Efendi, kendisine tevcih edilen bu görev dolayısıyla hem devletin talep ve alacaklarının kolaylıkla yerine getirileceğini hem de reayanın rahat edeceğini düşünmektedir. Keza padişah da hatt-1 hümâyûnunda "İnşallah Saruhan Sancağı yoluna girer" ifadesi ile Osman Efendi'nin memuriyetinin ne kadar önemli olduğuna vurgu yapmıştır. ${ }^{34}$ Saruhan Sancağı muhassıllık görevi için İzmit'ten harekete geçen ve 15 gün sonra Manisa'ya ulaşan Osman Efendi, sancakta meydana gelen asayiş olaylarını ${ }^{35}$, kanun ve nizamlara aykırı her türlü usulsüzlüğü takip etmiş ${ }^{36}$,

\footnotetext{
${ }^{31}$ BOA, HAT, 500/24482.

${ }^{32}$ Yücel Özkaya, “Anadoludaki Büyük Hanedanlıklar”, Belleten, C.LVI, Say1 217, Aralık 1992, s.834-835.

${ }^{33}$ M. Çağatay Uluçay, 18 ve 19. Yüzyıllarda Saruhan'da Eşkiyalık ve Halk Hareketleri, İstanbul 1955, s.282.

${ }^{34}$ Kereste Nazırı Osman Efendi'nin (aynı zamanda Saruhan Sancağı muhassılı) 7 Z 1231/29 Ekim 1816 tarihli kaimesi: BOA, HAT, 734/34846.

${ }^{35}$ Manisa'ya 2 saat uzaklıktaki Eğriköy'de sakin olan kesim ağalarından Sıracalığlu Hacı Ahmed Ağa’nın evi bir grup tarafından basılmış, eşyaları çalınmış ve ev halkı zarar görmüştür. Olayı araştıran Osman Efendi, işin Karaosmanzâdelerden Deli Süleyman Ağa ile bağlantısı olduğunu ortaya çıkarmıştır. Osman Efendi'nin 25 Z 1232/5 Kasım 1817 tarihli takriri: BOA, HAT, 718/34244). Osman Efendi, olayın arka planında yer alan Süleyman Ağa'nın Tuna sahilindeki bir kalenin inşasına memur edilmesi, Yakup Ağa ile Yetim Ahmed Ağa'nın ise İstanbul'a getirtilerek burada ikamet ettirilmesi veya başka bir yere gönderilmesi halinde sancağın tamamen temizleneceğini düşünmektedir (Osman Efendi'nin Selh-i Z 1232/10 Kasım 1817 tarihli kaimesi: BOA, HAT, 718/34233).

${ }^{36}$ Menemen kazasındaki Rum reaya, kiliselerinin avlusunda bulunan papaz odalarını yıktırarak yüksek bir şekilde inşa ettirmiş, kilise içinde bazı yerlere yeni direkler koydurmuştur. Olayı soruşturan Osman Efendi, tamir ve tadilatın ferman olmaksızın tamamen voyvodanın izniyle yapıldığını, 3 zimminin de bu durumun öteden beri bu şekilde devam ettiğini
} 
Karaosmanzâdelerin bölgedeki nüfuzunu yerinde görmüş, vefat eden Karaosmanzâde Hacı Hüseyin Ağa'nın muhallefâtının tespit edilmesinde büyük bir gayret göstermiş ve bu konuda merkezi s1k s1k bilgilendirmiştir. 1232/1816-1817 senesine mahsuben Manisa Sancağı mukataası iltizamen uhdesine verilen Osman Efendi, sancağın mukataa, zeamet ve timarların hasılatını tashih ve tahkik etmek üzere harekete geçmiştir. Osman Efendi'ye havale edilen işlerden birisi de vefat eden Karaosmanzâde Hacı Hüseyin Ağa'nın muhallefâtını eksiksiz bir şekilde tespit ettirerek kayda geçirmesidir. Bu konuda görevlendirilen mübaşir ile birçok müzakereler yapan Osman Efendi, kayda geçirilen muhallefât ve İstanbul'a gönderilen nakit dışında herhangi bir şey tespit edilemediğini, durumun Karaosmanzâdelerden Aydın Muhassılı Mehmed Ağa'dan da soruşturulduğunu ve muhallefâtın defterde yazılan kadar olduğunu merkeze bir yazı ile bildirmiştir. ${ }^{37}$ Konu hakkında padişaha sunulan bir takrirde, Muhassıl Osman Efendi'nin Karaosmanzâdelerin elindeki iltizamların hâsılatını ciddi olarak tahkik etse bile, ahalinin uzun süredir bunların idaresinde olmasından dolayı hiçbir şeyin ifşa edilmeyeceği belirtilmektedir. ${ }^{38}$ Merkez, muhallefât ile ilgili olarak gerek Osman Efendi'den gerekse muhallefât mübaşiri Abdi Bey'den gelen haberleri değerlendirdikten sonra muhallefâtın -daha önce miri için zapt edilen para ve diğer eşyanın mahsup edilerek- $5.000 \mathrm{kese}^{39}$ bedel ile vereseye birakılmasına karar vermiştir. $^{40}$ Sancağın idaresinde ise Osman Efendi'nin yerinde bırakılması veya Karaosmanzâdelere verilmesi seçenekleri de değerlendirilmiştir. Merkez, sancağın gelirleri hakkında Osman Efendi'nin yeterince duruma hâkim olamadığını, Karaosmanzâdelerin devlete herhangi bir hizmetlerinin geçmediğini göz önünde bulundurarak sancağın idaresinin üçüncü bir kişiye verilmesini gündeme getirmiştir. ${ }^{41}$ Sadrazam tarafından padişaha sunulan telhis sonucunda, Saruhan ve Aydın taraflarının ahvaline vâkıf olan Süleyman Ağa'ya ${ }^{42}$ vezirlik rütbesi verilerek Saruhan mütesellimliğine ilave olarak Aydın muhassılllı̆̆ tevcih edilmiştir. ${ }^{43}$

\section{Vakıf Kurucusu Olarak Osman Efendi}

Osmanlı coğrafyasının diğer birçok bölgesinde olduğu gibi İzmit’te de çok sayıda vakıf tesis edilmiştir. Şehirdeki vakıf kurucuları arasında hanedan mensupları, üst düzey devlet adamları ve varlıklı yerel eşraftan kişiler bulunduğu gibi bölgeye tayin edilen sancakbeyi, defterdar, mutasarrıf, kereste emini ya da nazırı gibi memurlar eliyle de çeşitli vakıflar

söylediklerini ifade etmiştir. Merkezin kararı ise izin alınmaksızın kilisede yapılan yerlerin yıktırılması için ferman gönderilmesi ve voyvodaya da "tehdit ve taziri havi” bir mektup yazılması yönünde olmuştur (BOA, HAT, 774/36302). ${ }^{37}$ Saruhan Sancağı Muhassılı Osman Efendi'nin 5 M 1232/25 Kasım 1816 tarihli kaimesi: BOA, HAT, 518/25333. Osman Efendi, merkeze gönderdiği bir başka şukkasında Karaosmanzâdeler ile görüştügünü, muhallefâtın kendilerine bırakılması halinde 4 bin kese akçeden fazla bedel vermeyeceklerinin anlaşıldığını, zira muhallefâtın takdir edilen kıymetleri fazlaca olduğundan 2.500 kese tutmayacağını, üstelik merhum Hüseyin Ağa'nın İstanbul'daki sarrafı ile Manisa'daki esnaf vs. kişilere borcu olduğunu ifade etmiştir. Karaosmanzâdeler ise sancağın zeamet, timar vs. iltizamların gerçek gelirlerinin ortaya çıkmasından sonra fazlasının iltizam bedeline ilave edilerek sancağın kendilerine ihale edilmesi ve muhallefâtla birlikte 7 bin kese bedel verme niyetini taşımaktadır. Merkezin tavrı, Karaosmanzâdelere güvensizliği gözler önüne sermekte ve bu durum padişahın hatt-1 hümâyûnunda "rical-i devletimden bir adem 6 aydır o tarafta ikamet eder. Ne muhallefâtı meydana korlar ve ne bedele talib oldular. Sancak ahara ihale olundukdan sonra uyanıp 7 bin kese dava ederler. Çünkü müteveffanın deyninden maada bir şeyi yoğumuş" ifadesiyle dile getirilmektedir (BOA, HAT, 518/25334).

${ }^{38}$ Yuzo Nagata, Tarihte Âŷ̂nlar Karaosmanoğulları Üzerinde Bir İnceleme, Ankara 1997, s.73-74.

391819 yılında bir kesenin karşılığı kîse-i Rûmî olarak 500 kuruş, kîse-i dîvânî olarak 60.000 akçe idi (Baki Çakır, "Kese", Türkiye Diyanet Vakfi İslam Ansiklopedisi, C. Ek-2, Ankara 2019, s.42).

${ }^{40}$ BOA, HAT, 517/25240.

${ }^{41}$ Merkez, sancağın cizye ve avarız gelirlerinin emanet olarak Osman Efendi'ye gönderilmesini istemiştir (BOA, HAT, $539 / 26589)$.

421817 yılında muhassıllığa getirilen Süleyman Ağa (Paşa)'ya 1818 yılı Martı'nda vezirlik rütbesinin yanı sıra Aydın Sancağı mutasarrıflı̆̆ı da verilmiştir. Süleyman Ağa Saruhan mütesellimliğine Karaosmanzâde Mehmed Ağa' yı tayin etmiş ve 1819'da Şam Valisi olarak oradan ayrılmıştır (Uluçay, 18 ve 19. Yüzyıllarda Saruhan'da Eşkiyalık ve Halk Hareketleri, s.282).

${ }^{43}$ Nagata, Tarihte Âyânlar, s.74-75.

Near East Historical Review

www.nehrreview.com 
kurulmuştur. $\mathrm{Bu}$ sayede şehir imar edilmiş, yeni eserlerle donatılmış, mevcut vakıflar desteklenmek suretiyle halkın ihtiyaçları karşılanmıştır.

Kereste emini veya nazırı olarak bölgeye gönderilen kişiler de sadece devlet hizmetini yerine getirmemiş, aynı zamanda şehre hizmet etmiştir. Osman Efendi'den önce de kereste emini olarak şehirde vakıf kuranlar ve hayır eserleri inşa ettirenler olmuştur. Mesela, Kereste Emini İbrahim Ağa, şehirde bir cami inşa ettirmiş ve masrafları için bazı gayrimenkuller bağışlamıştır. Bazı kereste eminleri şehirdeki vakıfların mütevellilik görevini üstlenmişlerdir. İzmit Kereste Emini Nuh Bey, bunlardan biri olup 1805 yılında Divzâde Hacı Mustafa Ağa Vakfı'nın mütevelliliğini yapmıştır. ${ }^{44}$

Moralı Osman Efendi de İzmit kereste nazırı iken 1 R 1230/13 Mart 1815 tarihinde tescil ettirdiği vakfiyesi ile kendi malından ayırdığg 2.000 kuruşu vakfetmiştir. Tescil işlemi, Osman Efendi'nin İzmit Tersanesi'nde ikamet ettiği yerde şahitlerin huzurunda yapılmış ve müderrislerden Seyyid İbrahim Hasib Efendi mütevelli olarak tayin edilmiştir. Vâkıf Osman Efendi, vakfettiği paranın onu on bir buçuk hesabı üzere (\%15 kâr ile) işletilmesini, paranın zayi olmasına sebep olacak kimselere verilmemesini, hali vakti yerinde olanların müracaatları halinde de "rehn-i kavî" ve "kefil-i ganî" olanların seçilmesini istemiş, bu şartları taşımayanlara kesinlikle vakıftan borç para verilmemesini talep etmiştir. Paranın işletilmesinden elde edilecek gelirin sarf alanları ise vakfiyede şu şekilde belirtilmiştir: Her yıl olmak üzere Pertev Mehmed Paşa Camii avlusunda bulunan medresenin müderrisi Hulusi Mehmed Efendi'ye 240 kuruş; müderrislerin ikamet ettiği hücrenin cam, çerçeve ve kiremit aktarması gibi küçük tamir işlerinde kullanılmak üzere 15 kuruş; vakfin tevliyet görevini yürütenlere 30 kuruş; İzmit'teki hâkim efendilere harc-1 muhasebe olarak 10 kuruş; mahkemedeki başkâtip efendilere ve hademeye 2'şer kuruş; kaydiye ve muhzırıyye olarak 1 kuruş verilmesi şart koşulmuştur. Müderrislere verilmesi şart koşulan y1ll1k 240 kuruş, 1 R1230/13 Mart 1815 tarihinden başlamak üzere 3 ayda bir 60'ar kuruş olacak şekilde mütevelli tarafından 4 taksit halinde teslim edilecektir. Müderrisler gerek medresede gerekse camide yararlı ilim ve fikıhla meşgul olup vâkıfı ve ailesini hayırla yâd edecek, Kur'an-1 Kerim okuyarak ruhlarına gönderecektir. Vâkıfın üzerinde durduğu noktalardan biri de müderrislik görevinin sadece ücretini düşünen cahil kimselere verilmemesi, imtihandan geçmiş ve göreve layık olan ulema efendiler arasından seçilenlere tevcih edilmesidir. Bu konuya İzmit kadısı ve ileri gelenlerin de nezaret ve dikkat etmesi istenmiştir. Tevliyet görevine getirilen Seyyid İbrahim Hasib Efendi'nin hayatta olduğu sürece bu görevi yürütmesi ve ölümü halinde yerine kadı ve ileri gelenlerin girişimiyle görevin üstesinden gelebilecek bir kişinin getirilmesi, şefaat ve rica ile ehil olmayanların müderris ve mütevelli yapılmaması vâkıfın zikrettiği diğer şartlar arasında bulunmaktadır. ${ }^{45}$

\section{Osman Efendi'nin İzmit Kereste Nazırı İken İstanbul'da İkameti}

Osman Efendi, İzmit’te kereste nazırı olarak görev yaptığı süre boyunca zaman zaman ailesini görmek üzere İstanbul'a gitmiştir. Bazen İstanbul'a gidişi hastalığı dolayısıyla olmuş ve tedavisi süresince burada kalmıştır. İstanbul'daki ikamet süresi, iklim ve sağlık koşulları ile İzmit’teki kereste işlerinin durumuna göre değişiklik göstermiştir. Merkez, Osman Efendi'nin İstanbul'a gelme konusundaki izin taleplerini şartlı olarak kabul etmiştir. Zira merkez, kereste

\footnotetext{
${ }^{44}$ Kerim Özdemir, İzmit Kazası Vakıflarl ve Vakıf Eserleri: Tespit ve Değerlendirme (1750-1850), Afyon Kocatepe Üniversitesi Sosyal Bilimler Enstitüsü, Yayımlanmamış Yüksek Lisans Tezi, Afyonkarahisar 2018, s.57-58, 63.

${ }^{45}$ Vakfın tesciline şahitlik edenler arasında Dergâh-1 âlî kapıcıbaşılarından Halil Paşa-zâde Seyyid Hüseyin Beyefendi, Hassa silahşorlardan belde ayanı Mehmed Tahir Ağa, eski ayan Hacı Ali Bey ile Mübayaacı Seyyid Ali Ağa, Hazînedâr Seyyid Memiş Efendi, vâkıfın kethüdası Hacı Eyüb Ağa, Kilerci Halil Ağa, Ser-Turnâcılardan Pehlivan Hacı Süleyman Ağa, Kirli-zâde Süleyman Ağa, Hacı Mustafa Ağa, Uzun Mustafa Ağa, Tüğsüz-zâde Süleyman Ağa, Tüğsüz-zâde SerTurnâyî İsmail Ağa, Nakib-zâde Seyyid İsmail Efendi ve Kaya-zâde Mustafa Bey bulunmaktadır (Akşener, İzmit Şer'iyye Sicili, s.165-167; Alper Ayhan, 1452 Numaralı İzmit Şer'iyyeSicili'nin Değerlendirilmesi ve Transkripsiyonu, Kafkas Üniversitesi Sosyal Bilimler Enstitüsü, Yayımlanmamış Yüksek Lisans Tezi, Kars 2013, s.83-84).
} 
işinde son derece titiz çalışan Osman Efendi'nin İzmit'ten ayrılmasını uygun görmemiş, İstanbul'da bir haftadan fazla ikamet etmeyip döneceğini ifade eden Osman Efendi'ye itimat ederek çocuklarını ve ailesini görmek üzere 5-10 gün izin vermiştir. ${ }^{46}$ İstanbul'a geliş zamanı Kurban Bayramı zamanına rastlayan Osman Efendi'ye biraz daha müsaade edilerek izni uzatılmıştır. Osman Efendi, İzmit'te yerine vekil olarak kethüdası Hacı Eyüp Ağa'yı bırakmış ve kereste işlerini yoluna koymuştur. İzin süresini dolduran Osman Efendi dönüş için hazırlık yaptığı sırada merkez, kış mevsiminin yaklaşmış olduğu ve bu mevsimde kereste kesilmesi ve naklinin söz konusu olmadığını göz önünde bulundurarak izin süresini nevruza kadar uzatmış ve İstanbul'daki evinde ikametine izin vermiştir. ${ }^{47}$ Bahara kadar İstanbul'da kalan Osman Efendi, izin süresinin dolduğunu ancak ihtiyarlığı dolayısıyla sağlığının bozuk olduğunu ve 15-20 gün kadar sahilhânesinde tedavi amaçlı olarak dinlenmek istediğini, İzmit'teki kereste işlerini vekil bıraktığı kişi vasıtasıyla takip edeceğini belirten bir yazı göndermiştir. Merkezin kararı, İzmit’te kereste işini takip eden ehliyetli biri olduktan sonra İstanbul'da kalmasında bir sakınca olmadığ ve sahilhânesine gitmesine izin verilmesi yönünde olmuştur. ${ }^{48}$ Anlaşıldığına göre Osman Efendi'nin sahilhânesindeki tedavisi yaşlılığı sebebiyle etkili olmamış ve sağlığı düzelmemiştir. Merkeze yazdığı yazıda hastalığını tekrar gündeme getiren Osman Efendi, İzmit'in havasının sağlığına iyi gelmeyeceğini beyan ile kereste işlerinin vekili Eyüp Ağa tarafindan sorunsuz bir şekilde idare edildiğini, kendisinin de işleri takip ettiğini ve merkezin kararına göre hareket edeceğini ifade etmiştir. Osman Efendi'nin iyileşememesi dolayısıyla yaza kadar sahilhânesinde ikametine izin veren merkez, kereste işlerinin kesintiye uğramaması için de İzmit'te bıraktığı vekiline "tenbihnâme" yazmasını emretmiştir. ${ }^{49}$

\section{5. İzmit Kereste Nazırı Osman Efendi’nin Vefatı ve Muhallefâtı}

Bir süredir sağlığı bozuk olan Kereste Nazırı Osman Efendi, ikamet ettiği sahilhânesinde 15 Temmuz 1818 tarihinde vefat etmiştir. Durumu, ölümünden bir gün sonra öğrenen merkez, Osman Efendi'nin son derece varlıklı ve servetiyle meşhur biri olduğunu biliyordu. Dolayısıyla yaşadığı konak ve sahilhânesinin mühürlenerek içindeki eşya ve malının kayıt altına alınması gerekiyordu. $\mathrm{Bu}$ konuda defterdara buyuruldu verilmesi ve yerine tayin edilecek kişinin seçilmesiyle ilgili padişahın kararı sorulmuştur. Padişah; "muma-ileyh eski ve işbilür adem idi, acıdım. Hak Teala rahmet eyleye. Emvâl ve eşyası tahrîr olunup ve uhdesinde olan mukata'ât vesair irâdı her ne ise başkaca defter olunup arz olunmasını defterdara havale eyleyesin. Hemân serian temhir ve tahrîr eyleyüp ve mukata'ât defterini bir kadem akdem tanzim ve takdim eyleyesün. Kereste nezâreti oldukça nüfûzlu bir ademe muhtaçdır. Hatıra gelen birkaç ademin isimlerini pusula edip arz eyleyesin" hattıyla hem Osman Efendi'nin ölümünden dolayı duyduğu üzüntüyü dile getirmiş hem de bu konuda atılacak adımları açıklığa kavuşturmuştur. ${ }^{50}$ İzmit Kereste Nezareti'ne seçilecek kişi üzerinde görüşmeler yapılmış ve kereste nezareti, İrfanzâde Arif Efendi'ye havale edilmiştir. Kereste işlerinin Osman Efendi'nin memuriyeti döneminde olduğu gibi belli bir düzen içinde yürütülmesi için Arif Efendi'nin, Osman Efendi'nin kethüdası ve vekili olan Hassa Silahşorlardan Hacı Eyüp Ağa'yı bir sene süreyle yanında istihdam etmesine karar verilmiştir. ${ }^{51}$

Osman Efendi'nin vefatından sonra gerek İstanbul'da gerekse İzmit'te bulunan eşyaları 18 Za 1233/19 Eylül 1818 tarihinden başlamak üzere çeşitli tarihlerde deftere kaydedilmiştir. Bu

\footnotetext{
${ }^{46}$ BOA, HAT, 299/17717 (Tarihsiz)

${ }^{47}$ BOA, HAT, 409/21258 (Tarihsiz).

${ }^{48} \mathrm{BOA}$, HAT, 667/32517 (Tarihsiz).

${ }^{49}$ BOA, HAT, 671/32811 (Tarihsiz)

${ }^{50}$ BOA, HAT, 679/33128 (Tarihsiz).

${ }^{51}$ BOA, HAT, 678/33035 (Tarihsiz). 1233 yılı Şevval ayı ortaları/18 Ağustos 1818'de Arif Efendi'nin yanına memur edilen Eyüp Ağa, bir yıllık sürenin sonunda hizmette kendisiyle ilgili bir iş kalmadığını beyan ederek İstanbul'a dönmesine izin verilmesini talep etmiş ve bu talebi kabul edilmiştir (10 ve $16 \mathrm{~S} \mathrm{1235/28} \mathrm{Kasım} \mathrm{ve} 4$ Aralık 1819 tarihli yazışmalar için bk. BOA, HAT, 1547/27. Ayrıca bk. BOA, Ali Emiri Sultan Mahmud II (AE.SMHD.II), 67/4815).
} 
defterde ev ve mutfak eşyaları, giyim eşyaları, berber takımları, tütün takımları, at takımları, silah ve silah takımları, yazı takımları, altın, gümüş, elmas gibi değerli madenlerden yapılmış eşyalar ile 400 civarında kitap bulunmaktadır. Osman Efendi İstanbul'daki sahilhânesinde vefat ettiğinden ilk kayıtlar burada bulunan eşyaların kayda geçirilmesiyle oluşmuş, cins, sayı ve değeri belirtilen eşyaların kimlere satıldığı not edilmiştir.

\section{Tablo I: Moralı Osman Efendi’nin Muhallefâtı ${ }^{52}$}

\begin{tabular}{|c|c|c|c|}
\hline Tarih & Satılan Eşyaların Cinsi & $\begin{array}{l}\text { Toplam } \\
\text { Değeri } \\
\text { (Kurus) }\end{array}$ & Satın Alan Kişiler \\
\hline $\begin{array}{l}\text { I. Defa }(18 \text { Za } \\
1233 / 19 \text { Eylül } \\
1818)\end{array}$ & $\begin{array}{l}\text { Yatak takımları, tütün } \\
\text { takımları, at takımları, ev } \\
\text { ve giyim eşyaları }\end{array}$ & 6.524 & $\begin{array}{l}\text { Kasabbaşı, sermimar, bina emini, tüccar, Hacı } \\
\text { Hüseyin Efendi, Necib Efendi, Salih Ağa. }\end{array}$ \\
\hline $\begin{array}{l}\text { II. Defa }(19 \mathrm{Za} \\
1233 / 20 \quad \text { Eylül } \\
1818)\end{array}$ & $\begin{array}{l}\text { At takımları, berber } \\
\text { takımları, giyim, ev ve } \\
\text { mutfak eşyaları, silahlar }\end{array}$ & 12.234 & $\begin{array}{l}\text { Reis Efendi, serçavuş, sergulam ağa, Yeniçeriyan- } \\
1 \text { sermehteran, serçavuşan-1 humbaracıyan, tüccar, } \\
\text { arpa emini, sermimaran, kasabbaşı, Yusuf Efendi, } \\
\text { Seyyid Emrullah, Hacı Hüseyin Efendi, Hacı } \\
\text { Mehmed Ağa, Salih Ağa, Şerif Ağa. }\end{array}$ \\
\hline $\begin{array}{l}\text { III. Defa }(22 \mathrm{Za} \\
1233 / 23 \quad \text { Eylül } \\
1818)\end{array}$ & $\begin{array}{l}\text { At takımları, silah } \\
\text { takımları, giyim, ev ve } \\
\text { mutfak eşyaları, çeşitli } \\
\text { saatler, şahsi eşyalar }\end{array}$ & 61.185 & $\begin{array}{l}\text { Serçavuş, sercebe, sermimar, tüccar, bina emini, } \\
\text { matbah emini, kasabbaşı, kâtip efendi, Hasan } \\
\text { Ramiz Efendi, Seyyid Emrullah, Hacı Hüseyin } \\
\text { Efendi, Rasim Efendi, Hacı Mehmed Ağa, Hacı } \\
\text { Ali, Şermin Ağa, Salih Ağa, Sadullah Bey, Kara } \\
\text { İsmail. }\end{array}$ \\
\hline $\begin{array}{l}\text { IV. Defa }(25 \mathrm{Za} \\
1233 / 26 \quad \text { Eylül } \\
1818)\end{array}$ & $\begin{array}{l}\text { Çok sayıda kürk ve giyim } \\
\text { eşyası, ev eşyaları, silah } \\
\text { takımları, yazı aletleri, } \\
\text { Kur'an-1 Kerim }\end{array}$ & $61.312,5$ & $\begin{array}{l}\text { Serçavuş, sermimar, sertopi, serbostaniyan, bina } \\
\text { emini, kasabbaşı, kâtip efendi, sergulam ağa, } \\
\text { tüccar, Numan Efendi, Hacı Hüseyin Efendi, Hacı } \\
\text { Ali, Salih Ağa, Ahmed Ağa. }\end{array}$ \\
\hline $\begin{array}{l}\text { V. Defa }(26 \mathrm{Za} \\
1233 / 27 \text { Eylül } \\
1818)\end{array}$ & $\begin{array}{l}\text { Giyim, ev ve mutfak } \\
\text { eşyaları, at takımları, silah } \\
\text { ve silah takımları, tütün } \\
\text { aletleri, alet ve edevat }\end{array}$ & 31.381 & $\begin{array}{l}\text { Serbostaniyan, bina emini, kasabbaş1, sergulam } \\
\text { ağa, bedesten kethüdas1, tüccar, Numan Efendi, } \\
\text { Hacı Hüseyin Efendi, Rasim Efendi, Hacı Selim, } \\
\text { Salih Ağa, Sadullah Bey, İstanbul Ağası. }\end{array}$ \\
\hline $\begin{array}{l}\text { VI. Defa }(27 \mathrm{Za} \\
1233 / 28 \quad \text { Eylül } \\
1818)\end{array}$ & $\begin{array}{l}\text { Ev eşyaları, bakır } \text { kap } \\
\text { kacak, silahlar, at } \\
\text { takımları, kitaplar }\end{array}$ & 9.353 & $\begin{array}{l}\text { Sermimar, sercebeci, serbostaniyan,kasabbaş1, } \\
\text { sergulam-1 cizye, salyaneci, tüccar, Hacı Hüseyin } \\
\text { Efendi, Hac1 Selim, Hasan Ağa, Kara İsmail, } \\
\text { İsmail Efendi, Necib Efendi, Yusuf Efendi. }\end{array}$ \\
\hline $\begin{array}{l}\text { İzmit tarafindan } \\
\text { getirip satılan } \\
\text { eşyası }\end{array}$ & At takımları, silahlar & 2.228 & Kasabbaşı, Salih Ağa, Ahmed Ağa. \\
\hline $\begin{array}{l}\text { Sahilhânesinde } \\
\text { satılan eşyası }\end{array}$ & $\begin{array}{l}\text { Ev ve mutfak eşyası, } \\
\text { kahve }\end{array}$ & 9.005 & $\begin{array}{l}\text { Sermehteran, Esad } \text { Beyefendi, } \\
\text { Hazinedar İsmail Ağa, Halim Ağa. }\end{array}$ \\
\hline $\begin{array}{l}\text { Satılan kitaplar1 } \\
\text { I. Defa }(1 \quad M \\
1234 / 31 \quad \text { Ekim } \\
1818)\end{array}$ & 111 cilt kitap & 23.808 & $\begin{array}{l}\text { Reis efendi, kâtip efendi, sermimaran, servezzan, } \\
\text { tüccar, Hacı Hüseyin Efendi, Salih Ağa, Seyyid } \\
\text { Emrullah, Hasan Ramiz Efendi. }\end{array}$ \\
\hline $\begin{array}{l}\text { II. Defa }(2 \quad \mathrm{M} \\
1234 / 1 \quad \text { Kasim } \\
1818)\end{array}$ & 117 cilt kitap & 1.524 & $\begin{array}{l}\text { Kâtip Efendi, servezzan, Hacı Ali, Ahmed Resmi } \\
\text { Efendi, Hasan Ramiz Efendi, Hafız Musa Efendi, } \\
\text { Kara İsmail, Seyyid Emrullah. }\end{array}$ \\
\hline $\begin{array}{l}\text { III. Defa }(6 \mathrm{M} \\
1234 / 5 \quad \text { Kasim } \\
1818)\end{array}$ & $\begin{array}{l}169 \text { cilt kitap, sandık ve } \\
\text { kalemtraş }\end{array}$ & 6.828 & $\begin{array}{l}\text { Sermimaran-1 hassa, bölükbaşı, kâtip efendi, } \\
\text { sergulam ağa, sercebeci, tüccar, Hafiz Musa } \\
\text { Efendi, Salih Ağa, Rasim Efendi, Haseki Seyyid } \\
\text { Mustafa Efendi, Seyyid Emrullah, Salih Efendi, } \\
\text { Numan Efendi, Arapoğlu. }\end{array}$ \\
\hline \multicolumn{2}{|c|}{ YEKÛN MUHALLEFÂT } & 225.382 & \\
\hline
\end{tabular}

${ }^{52}$ BOA, Bâb-ı Defteri Baş Muhasebe Muhallefât Halifeliği Kalemi Defterleri (D.BŞM.MHF.d.), 13283, s.2-17. 
Osman Efendi'nin muhallefâtında dikkat çeken birkaç nokta üzerinde durmak gerekmektedir. Bunlardan biri, ev eşyaları arasında son derece değerli bazı eşyaların bulunmasıdır. Özellikle 4.050 kuruş değerinde çalar saat ile 3.250 kuruş değerindeki altın saat; 1.600 kuruş değerindeki elmaslı altın fincan ve zarf sayılabilir. Ayrıca Osman Efendi, bulunduğu konum ve görevleri gereği çok sayıda ve çeşitte kürk, cübbe ve biniş edinmiştir. Samur, kakım, tilki ve vaşak derisinden imal edilen kürkleriyle birlikte biniş ve cübbelerinin sayısı 20 adetten fazladır. At takımları ve silah takımları da tür ve kıymet olarak dikkat çekicidir. At takımları arasında, yaldızlı gümüş kabaralı ve sırma işlemeli olmak üzere al, güvez, mavi, pembe, nefti çuka gaşiye, yaldızlı gümüş raht ile başlık ve rişmeler, gümüş ve bakır rişme, sırmalı ve minekâri kesme, yaldızlı demir rikâb bulunmaktadır. Silah ve silah takımlarının sayıca çok olması ise Osman Efendi'nin yaptığı görevlerle ilgili olmalıdır. İstanbul'da uzun yıllar bürokraside görev alması, İzmit'te kereste nazırı olarak bölgenin asayiş işlerini de takip etmesi, Saruhan gibi güçlü ayanların bulunduğu bir bölgeye muhassıl olarak gönderilmesi Osman Efendi'nin çok sayıda silah edinmesine yol açmış ve bunun sonucu olarak hatırı sayılır bir silah koleksiyonu ortaya çıkmıştır. Ok, mızrak, kılıç, balta, gaddare gibi kesici ve delici silahlara sahip olan Osman Efendi'nin bu silahlarının altın takımlı ve gümüş olduğu görülmektedir. Terekede, ateşli silahlar olarak filinta, şeşhane, piştov ve tüfek daha yaygın olarak yer almış; 2 adet filinta; 10 adet şeşhane; 10 adet piştov ve 19 adet tüfek kayıtlara geçmiştir. Piştovlar, altın veya elmaslı altın minekâri takımlı, yaldızlı simli, simli, sırma kuburlu olmak üzere çeşitli özelliklerde imal edilmiştir. Tüfekler ise kaval tüfek, mercanlı alay tüfeği, mercan konmalı tüfek, konmalı alay tüfeği ve tüfek olmak üzere terekedeki yerini almıştır. ${ }^{53}$

Osman Efendi'nin muhallefâtında üzerinde durulması gereken önemli bir husus da sahip olduğu kitaplarıdır. Maliyede yetişerek birçok memuriyette bulunması ve mesleği gereği okumak durumunda olması, onun iyi bir kütüphane oluşturmasına vesile olmuştur. Muhallefâtındaki eşyalarla birlikte ve üç ayrı kayıt halinde (1, 2 ve 6 M 1234/31 Ekim, 1 ve 5 Kasım 1818) deftere kaydedilen 400 civarındaki kitabı, aralarında ilmiye mensuplarının da bulunduğu çeşitli şahıslara satılmıştır. Kitapların içinde biri 750 kuruş, diğeri 2.250 kuruş değerinde olmak üzere iki Mushaf1 şerif bulunmaktadır ki bunlardan biri altın bir kese içerisindedir. Kütüphanenin en değerli parçası ise 10 ciltten oluşan Şerh-i Buhârî (Yusuf Efendi) olup 6.600 kuruşa Kâtip Efendi'ye satılmıştır. Kur'an-1 Kerim, tefsir, hadis, fikıh, akaid, meani-belagat, nahiv, hikmet, lügat, tarih ve tasavvuf gibi çeşitli alanlara ait olan bu kitaplar toplam terekenin (225.382 kuruş) kıymet olarak $\% 14$ 'ünden fazlasını oluşturmaktadır. ${ }^{54}$

Osman Efendi'nin İstanbul ve İzmit dışında, aile köklerinin dayandığı Mora'da da gayrimenkulleri bulunuyordu. Ölümünden sonra Mora'daki Karitene, Androsa, Gördüs, Trapoliçe ve Ayapetros kazalarında bulunan çiftlik ve arazilerine miri tarafindan el konulmuştur. Osman Efendi'nin bu arazilerde değiş̧en oranlarda hissesi bulunmaktadır. Mesela, Karitene kazasındaki 5 adet çiftliğin 3/4'ü ile 1 adet çiftliğin 1/3'ü; Androsa kazasındaki çiftliğin 1/6'si; Gördüs kazasındaki çiftliğin yarısı; Trapoliçe ve Ayapetros kazalarındaki 1 adet çiftlik ile diğer bir çiftliğin 1/6'sına sahip olan Osman Efendi'nin Perçova ve diğer bölgelerde de tarlaları mevcuttu. Bahsedilen çiftliklerdeki hisseler ile tarlalar muaccelelerini ödemek suretiyle Osman Efendi'nin kardeşi Yusuf Agâh Efendi'nin oğlu Seyyid Mehmed Nazif Efendi ile annesi Latif Kadın bint-i Abdullah'a müşterek olarak tevcih edilmiş ve mülknameleri verilmiştir. Tahsil edilen muacceleler ise mevaciblerin ödenmesi amaciyla Hazîne-i Âmire'ye teslim edilmiştir. ${ }^{55}$

\footnotetext{
${ }^{53}$ BOA, D.BSSM.MHF.d., 13283, s.2-11.

${ }^{54}$ BOA, D.BSSM.MHF.d., 13283, s.14-17.

${ }^{55}$ BOA, Cevdet Maliye (C.ML), 744/30304 (14 ve 19 S 1234/13 ve 18 Aralık 1818 tarihli yazışmalar).
} 


\section{Sonuç}

Bürokraside yetişmiş ve birçok memuriyette başarılı hizmetlerde bulunmuş olan Osman Efendi, merkezdeki faaliyetlerinin bir yansıması olarak taşrada önemli görevlere getirilmiş, karışık ve çözülmesi güç olan meselelerde bir çözüm unsuru olarak görülmüştür. 5 yıl süren İzmit kereste nazırlığ 1 döneminde merkezle sürekli irtibat halinde olan Osman Efendi'nin memuriyeti, kuşkusuz son derece önemli idi. Zira bu görev, doğrudan donanma ve tersaneyi ilgilendiriyor, gemilerin inşa ve tamirindeki düzeni etkiliyordu. Tayini gündeme geldiğinde, merkezin "mücerred şu kereste maddesi dolaşığı çözülsün" düşüncesi aslında Osman Efendi’nin bu işin üstesinden gelebilecek bir kişi olarak görüldügünü ortaya koymaktadır. Nitekim Osman Efendi, Tersâne-i Âmire ve İzmit Tersanesi'nin kereste ihtiyacının sorunsuz bir şekilde karşılanmasında büyük bir gayret göstermiş, birikmiş sorunların çözümünde yerel görevliler ve bölge halkıyla çeşitli müzakereler yapmıştır. Ayrıca kerestenin temin ve nakliyatını sekteye uğratabilecek güvenlik ve asayiş olaylarında son derece titiz davranmış, gelişmelerden an be an merkezi haberdar etmiştir. Bölgedeki ayanların hareketlerinin izlenmesi, eşkıyanın yakalanması, reayanın korunup kollanması, Sakarya Nehri-Sapanca Gölü-İzmit Körfezi'nin kanalla birleştirilmesi, İzmit Tersanesi'nin genişletilmesi gibi çalışmalar ona havale edilen diğer işler arasında bulunmaktadır. İşbilir ve yetenekli bir devlet adamı olmasının yanı sıra hayırsever bir kişiliğe de sahip olan Osman Efendi, kurduğu para vakfi ile Pertev Mehmed Paşa Camii avlusunda bulunan medresenin ihtiyaçlarını karşılamış, şehrin eğitim hayatına katkıda bulunmuştur.

Son memuriyeti, Saruhan nazırlığı olan Osman Efendi'nin bölgede nüfuzlu bir aile olan Karaosmanzâdelere karşı merkezi otoriteyi hâkim kılmak ve miri gelirleri tahsil etmek amaciyla Manisa'ya gönderildiği ve kendisinden çok şey beklendiği anlaşılmaktadır. Ancak bu görevde Osman Efendi, merkezin beklentilerine cevap verememiştir.

Hayatının son aylarını hasta olarak geçiren ve sık sık tedavi amaçlı İstanbul'a gidip gelen Osman Efendi, 1818 yılında burada vefat etmiştir. Ölümünden kısa süre sonra muhallefâtı kayda geçirilmiş ve 225.382 kuruşluk bir mal varlığı tespit edilmiştir. Muhallefâtındaki yaklaşık 400 ciltlik kitap koleksiyonu onun okumaya, öğrenmeye önem verdiğini, entelektüel bir kişiliğe sahip olduğunu göstermektedir. Gerek toplumsal gerekse şer'i meselelere duyarlılık göstermiş, bu konuda takrir ve kitaplar kaleme almıştır. 


\section{KAYNAKÇA}

\section{Arşiv Belgeleri}

\section{Cumhurbaşkanlığı Devlet Arşivleri Başkanlığı Osmanlı Arşivi (BOA)}

BOA, Ali Emiri Sultan Mahmud II (AE.SMHD.II), 67/4815.

BOA, Bâb-ı Defteri Baş Muhasebe Muhallefât Halifeliği Kalemi Defterleri (D.BŞM.MHF.d.), 13283, s.2-17.

BOA, Cevdet Bahriye (C.BH), 68/3210, 81/3891, 101/4895, 113/5469, 137/6623.

BOA, Cevdet Maliye (C.ML), 744/30304.

BOA, Hatt-ı Hümâyûn (HAT), 286/17170, 299/17717, 409/21258, 500/24482, 506/24903, 517/25240, 518/25333, 518/25334, 539/26589, 631/31171, 667/32517, 671/32811, 678/33035, 679/33128, 718/34233, 718/34244, 734/34846, 774/36302, 1262/48869B, 1313/51185, 1547/27, 1591/18.

BOA, Topkapı Sarayı Müzesi Arşivi Evrak (TSMA.E.), 710/39.

\section{Kaynak Eserler}

34

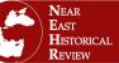

$11 / 2$

April

2021

Mehmed Süreyya, Sicill-i Osmanî, 4, Yayına Hazırlayan: Nuri Akbayar, Eski Yazıdan Aktaran; Seyit Ali Kahraman, İstanbul 1996.

Şânî-zâde Târîhi, C.2, Dersaadet 1290.

\section{Araştırma ve İncelemeler}

Akşener, Meral, İzmit Şer'iyye Sicili (4 Muharrem 1220-25 Şevval 1230) (4 Nisan 1805-30 Kasım 1814), Marmara Üniversitesi Türkiyat Araştırmaları Enstitüsü, Yayımlanmamış Doktora Tezi, İstanbul 1992.

Ayhan, Alper, 1452 Numaralı İzmit Şer'iyyeSicili'nin Değerlendirilmesi ve Transkripsiyonu, Kafkas Üniversitesi Sosyal Bilimler Enstitüsü, Yayımlanmamış Yüksek Lisans Tezi, Kars 2013.

Bostan, İdris, Osmanlı Bahriye Teşkilâtı: XVII. Yüzyılda Tersâne-i Âmire, Ankara 1992.

Bulmuş, Birsen, “Osmanlı İmparatorluğu'nda Veba Kavramları Üzerine: Mistisizimden Sosyal Reforma", Motif Akademi Halkbilimi Dergisi, C.3, S.6, Y11 2010, s.45-51.

Çakır, Baki, "Kese", Türkiye Diyanet Vakfi İslam Ansiklopedisi, C. Ek-2, Ankara 2019, s.42-43.

Çetin, Atilla, “Adapazarı Âyanı Kara Osman Ağa Vakfı ve Vakfiyesi”, Vakıflar Dergisi, S.30, Ankara 2007, s.155-183.

Çetin, Atilla, "Kocaeli ve Hüdavendigar Sancaklarında Eşkiyalık Olayları (18. ve 19. Yüzyıllar)”, Osmanlı'dan Günümüze Eşklyalık ve Terör, Ed. Osman Köse, Samsun 2017, s.135-157.

Derin, Fahri Ç., Yayla İmâmı Risâlesi, İstanbul Üniversitesi Edebiyat Fakültesi Tarih Enstitüsü Dergisi, Say1 3, Ekim 1972, İstanbul 1973, s.213-272. 
Erkal, Mehmet, "Arşın”, Türkiye Diyanet Vakfi İslam Ansiklopedisi, C.3, İstanbul 1991, s.411413.

Kalıpçı, Mahmud Esad, "Müsadere Kurumunda Islaha Dair Bir Teklif: III. Selim Dönemine Ait Bir Vesika", https://dergipark.org.tr/tr/download/article-file/272849 s.253-284 (E.T.15.03.2020).

Nagata, Yuzo, Tarihte Âŷnlar Karaosmanoğulları Üzerinde Bir İnceleme, Ankara 1997.

Narin, Resül, “Osmanlı'dan Cumhuriyet'e Ağaç Denizi Kocaeli”, Uluslararası Çoban Mustafa Paşa ve Kocaeli Tarihi-Kültürü Sempozyumu-IV, Kocaeli 2017, s.971-997.

Narin, Resül, “Osmanlı Devleti Zamanında Kocaeli Ormanları”, Belleten, C.LXXV, Sayı 274, Aralık 2011, s.769-782.

Özdemir, Kerim, İmit Kazası Vakıflart ve Vakıf Eserleri: Tespit ve Değerlendirme (1750-1850), Afyon Kocatepe Üniversitesi Sosyal Bilimler Enstitüsü, Yayımlanmamış Yüksek Lisans Tezi, Afyonkarahisar 2018.

Özkaya, Yücel, “Anadoludaki Büyük Hanedanlıklar”, Belleten, C.LVI, Sayı 217, Aralık 1992, s.809-845.

Uluçay, M. Çağatay, 18 ve 19. Yüzyıllarda Saruhan'da Eşkiyalık ve Halk Hareketleri, İstanbul 1955.

Uzunçarşı11, İsmail Hakkı, "Sakarya Nehrinin İzmit Körfezine Akıtılmasiyle Marmara ve Karadenizin Birleştirilmesi Hakkında", Belleten, C.IV, Sayı 14-15, Nisan-Temmuz 1940, Ankara 1994, s. 149-174. 


\section{EKLER}

EK 1: İzmit Kereste Nazırı Osman Efendi’nin Kereste Tertibi Hakkında Merkeze Yazdı ̆̆ Șukka

C.BH.00101.04895.002 
EK 2: Osman Efendi’nin Adapazarı Ayanı Kara Osman Ağa'nın Eşkıyalığı Hakkında Merkeze Gönderdiği Şukka

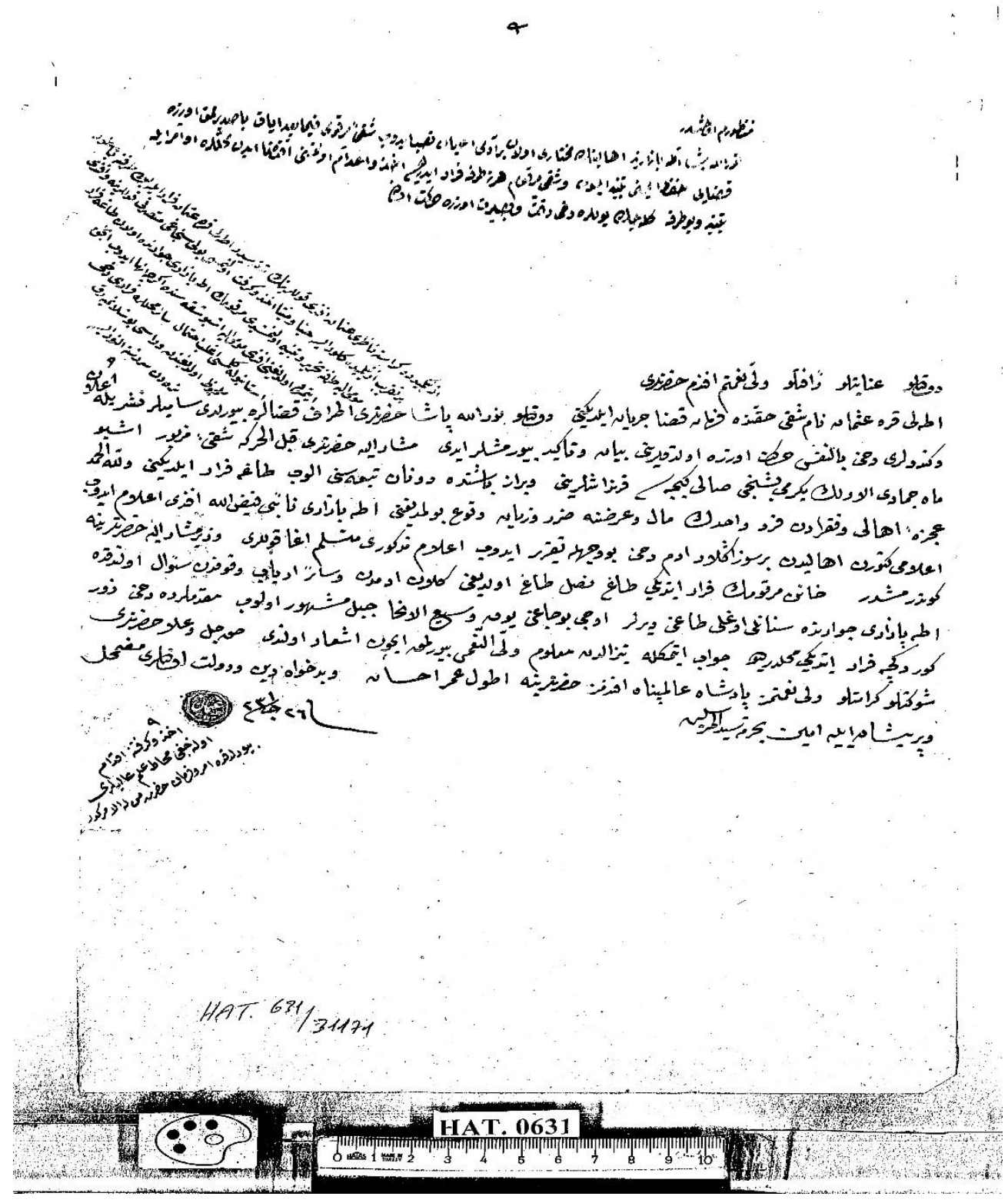


EK 3: Kereste Nazırı Osman Efendi'nin (Aynı Zamanda Saruhan Sancağı Muhassı11) 7 Z 1231/29 Ekim 1816 Tarihli Kaimesi

38<smiles>[c]1ccccc1</smiles>

$+1,2+8$

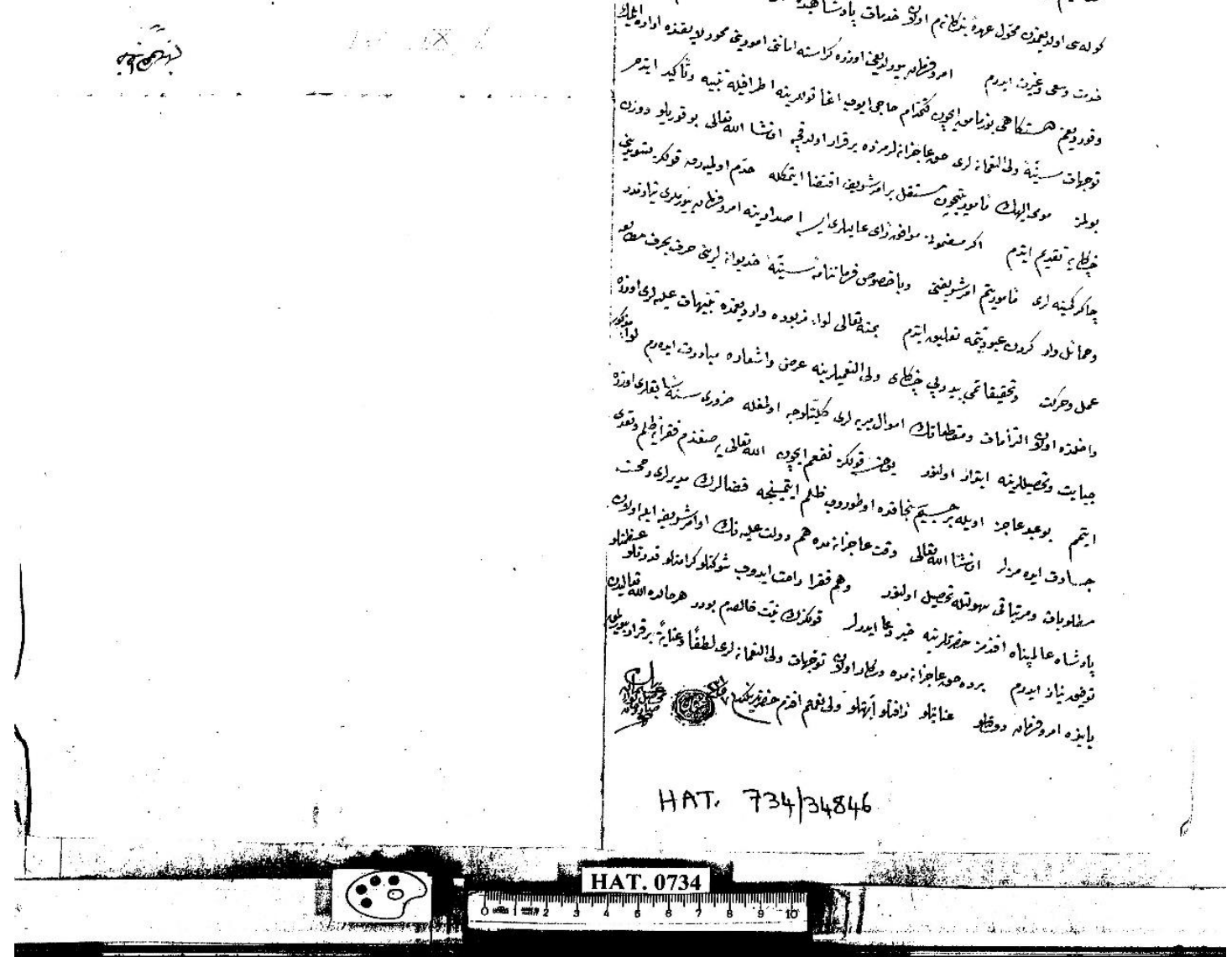

Near East Historical Review

www.nehrreview.com 
EK4: Osman Efendi’nin Muhallefâtı (İlk İki Sayfa)

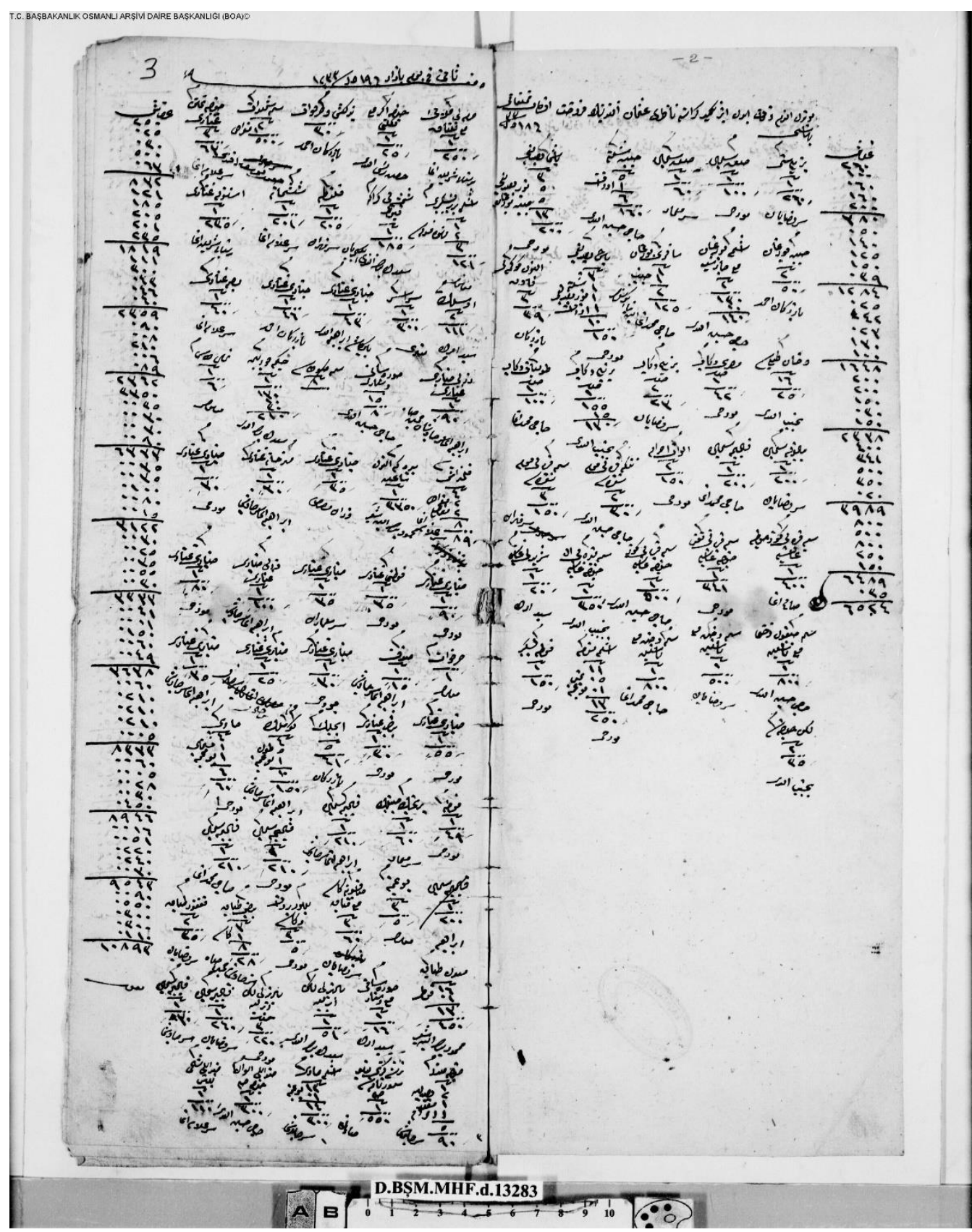

